\title{
CLOUDS, AEROSOLS, AND PRECIPITATION IN THE MARINE BOUNDARY LAYER An ARM Mobile Facility Deployment
}

by Robert Wood, Matthew Wyant, Christopher S. Bretherton, Jasmine Rémillard, Pavlos Kollias, Jennifer Fletcher, Jayson Stemmler, Simone de Szoeke, Sandra Yuter, Matthew Miller, David Mechem,

George Tselioudis, J. Christine Chiu, Julian A. L. Mann, Ewan J. O’Connor, Robin J. Hogan, Xiquan Dong, Mark Miller, Virendra Ghate, Anne Jefferson, Qilong Min, Patrick Minnis, Rabindra Palikonda, Bruce Albrecht, Ed luke, Cecile Hannay, and Yanluan Lin

\section{A 21 -month deployment to Graciosa Island in the northeastern Atlantic Ocean is providing an unprecedented record of the clouds, aerosols, and meteorology in a poorly sampled remote marine environment.}

$\mathrm{T}$ he complex interactions among clouds, aerosols, and precipitation are major sources of uncertainty in our ability to predict past and future climate change (Lohmann and Feichter 2005; Stevens and Feingold 2009; Quaas et al. 2009; Isaksen et al. 2009). Marine low clouds are particularly susceptible to perturbations in aerosols because they are spatially extensive (Warren et al. 1988), are relatively optically thin (e.g., Turner et al. 2007; Leahy et al. 2012), and often form in pristine air masses (Platnick and Twomey 1994). Increases in aerosol concentrations due to anthropogenic emissions lead to increases in cloud droplet concentration that increase cloud brightness by increasing the overall surface area of droplets. These aerosol indirect effects (AIEs) are the dominant contributor to the overall aerosol radiative forcing in most climate models, yet they are extremely poorly constrained and can vary by a factor of 5 across models (Quaas et al. 2009).

Climate models indicate that a major fraction of the global aerosol indirect radiative forcing signal is associated with marine low clouds (Quaas et al. 2009;
Kooperman et al. 2012, Fig. 3), which are poorly simulated in climate models (Zhang et al. 2005; Wyant et al. 2010). A range of models from simple theoretical models to sophisticated cloud-resolving simulations all indicate that the Twomey effect (increased cloud reflectance stemming from the reduction of drop size by condensation on a larger number of nuclei) is by itself insufficient to explain how low clouds respond to changes in aerosols. They show that a significant fraction of the overall aerosol indirect effect may be related to precipitation suppression by aerosols and its impact upon the turbulent kinetic energy and moisture budget of the boundary layer (Albrecht 1989; Ackerman et al. 2004; Lohmann and Feichter 2005; Penner et al. 2006; Wood 2007). Because a significant fraction of the precipitation falling from low clouds evaporates before reaching the surface (Comstock et al. 2004), this adds additional complexity to the ways in which precipitation can impact cloud dynamical responses to aerosols.

Recent field measurements are shedding important new light on the factors controlling precipitation

Publisher's Note: This article was revised on 13 May 2015. The unreferenced citation, Draxler and Rolph (2003) in Fig. 7, is replaced with Draxler (1999). 
rates in marine low clouds and particularly the role that aerosols may play in suppressing it (Wood 2005; Geoffroy et al. 2008; Wood 2012; Terai et al. 2012). These studies all show that, for a given amount of condensate or cloud thickness, precipitation from low clouds decreases with increasing cloud droplet concentration. However, existing field datasets are statistically limited by a relatively low number of cases. As such, it has proven challenging to fully understand the role of precipitation suppression by aerosols. Spaceborne cloud radar overcomes some of these sampling limitations and provides evidence that light precipitation is susceptible to increased concentrations of droplets (e.g., Kubar et al. 2009; Wood et al. 2009) and aerosols (L'Ecuyer et al. 2009). However, current spaceborne radar data suffer some limitations such as low sensitivity, low vertical resolution, and near-surface ground clutter contamination. In addition, spaceborne aerosol column-integrated aerosol optical property retrievals do not necessarily provide good constraints on cloud condensation nuclei concentrations (Liu and Li 2014). There is, therefore, a need to increase our surface sampling of aerosol-cloud-precipitation processes using state-ofthe-art remote sensing in conjunction with groundbased in situ measurements of aerosol optical and cloud-forming properties.

The need for improved long-term but comprehensive measurements at a marine low-cloud site motivated the Clouds, Aerosol, and Precipitation in the Marine Boundary Layer (CAP-MBL; www.arm .gov/sites/amf/grw) deployment of the U.S. Department of Energy Atmospheric Radiation Measurement Program (ARM) Mobile Facility (AMF) to the island of Graciosa in the eastern Atlantic Ocean. Graciosa is a small island $\left(\sim 60-\mathrm{km}^{2}\right.$ area $)$ situated at $39.1^{\circ} \mathrm{N}$, $28.0^{\circ} \mathrm{W}$ in the Azores Archipelago (Fig. 1), at a latitude that straddles the boundary between the subtropics and the midlatitudes. As such, Graciosa is subject to a wide range of different meteorological conditions, including periods of relatively undisturbed trade wind flow, midlatitude cyclonic systems and associated fronts, and periods of extensive low-level cloudiness. Measurements were made from April 2009 to December 2010.

CAP-MBL was designed to gather an extended record of high-quality data on clouds and aerosol properties in a remote marine environment needed to improve the treatment of clouds and aerosols in climate models. An important additional consideration for the deployment is the ability to provide high-quality ground-based remote sensing and in situ data that can be used in conjunction with spaceborne remote sensing to provide improved mapping and understanding of the properties of marine low clouds over the remote oceans. The CAP-MBL deployment's continuous record also allows for greater statistical reliability in the observed relationships between aerosols, clouds, and precipitation than is possible with aircraft yet retains the advantages of in situ sampling of aerosol properties that are difficult to constrain with satellite data. Table 1 lists the key science questions that the CAP-MBL deployment is designed to address.

OBSERVATIONS. Table 2 details the suite of remote sensing instrumentation deployed as part of the campaign, and Table 3 describes the in situ measurements. These tables also provide information describing the physical variables derived from the instrumentation. The AMF measurements were
AfFiliations: Wood, Wyant, Bretherton, Fletcher, and StemmlerDepartment of Atmospheric Sciences, University of Washington, Seattle, Washington; RÉmILLARD AND TSELIOUDIS—Columbia University, New York, New York; Kolulas_McGill University, Montreal, Quebec, Canada; DE SZOEKE-Oregon State University, Corvallis, Oregon; Yuter AND Miller-North Carolina State University, Raleigh, North Carolina; MeCHEM - University of Kansas, Lawrence, Kansas; $\mathrm{CHIU}_{\text {, }}$ MANN, AND Hogan-University of Reading, Reading, United Kingdom; O'CONNOR - University of Reading, Reading, United Kingdom, and Finnish Meteorological Institute, Helsinki, Finland; DoNG-University of North Dakota, Grand Forks, North Dakota; MilleR—Rutgers, The State University of New Jersey, New Brunswick, New Jersey; GHATEArgonne National Laboratory, Lemont, Illinois; JefFeRSON-CIRES, University of Colorado Boulder, Boulder, Colorado; MIN-University at Albany, State University of New York, Albany, New York; MinNisNASA Langley Research Center, Hampton, Virginia; PALIKONDAScience Systems and Applications, Inc., Hampton, Virginia; ALBRECHT-
University of Miami, Coral Gables, Florida; LUKE-Brookhaven National Laboratory, Upton, New York; JANNAY-National Center for Atmospheric Research,* Boulder, Colorado; LIN-Ministry of Education Key Laboratory for Earth System Modeling, Center for Earth System Science, Tsinghua University, Beijing, China * The National Center for Atmospheric Research is sponsored by the National Science Foundation.

CORRESPONDING AUTHOR: Robert Wood, Department of Atmospheric Sciences, University of Washington, P.O. Box 351640, Seattle, WA 98195

E-mail: wood.jcli@ametsoc.org

The abstract for this article can be found in this issue, following the table of contents.

DOI:I0.1175/BAMS-D-13-00180.1

In final form 23 May 2014

(C)2015 American Meteorological Society 


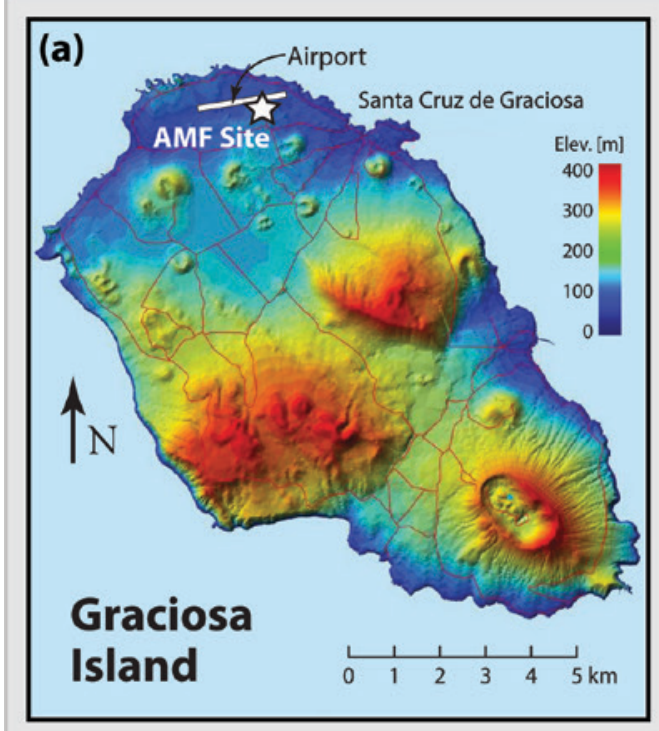

\section{Annual mean cloud droplet concentration}
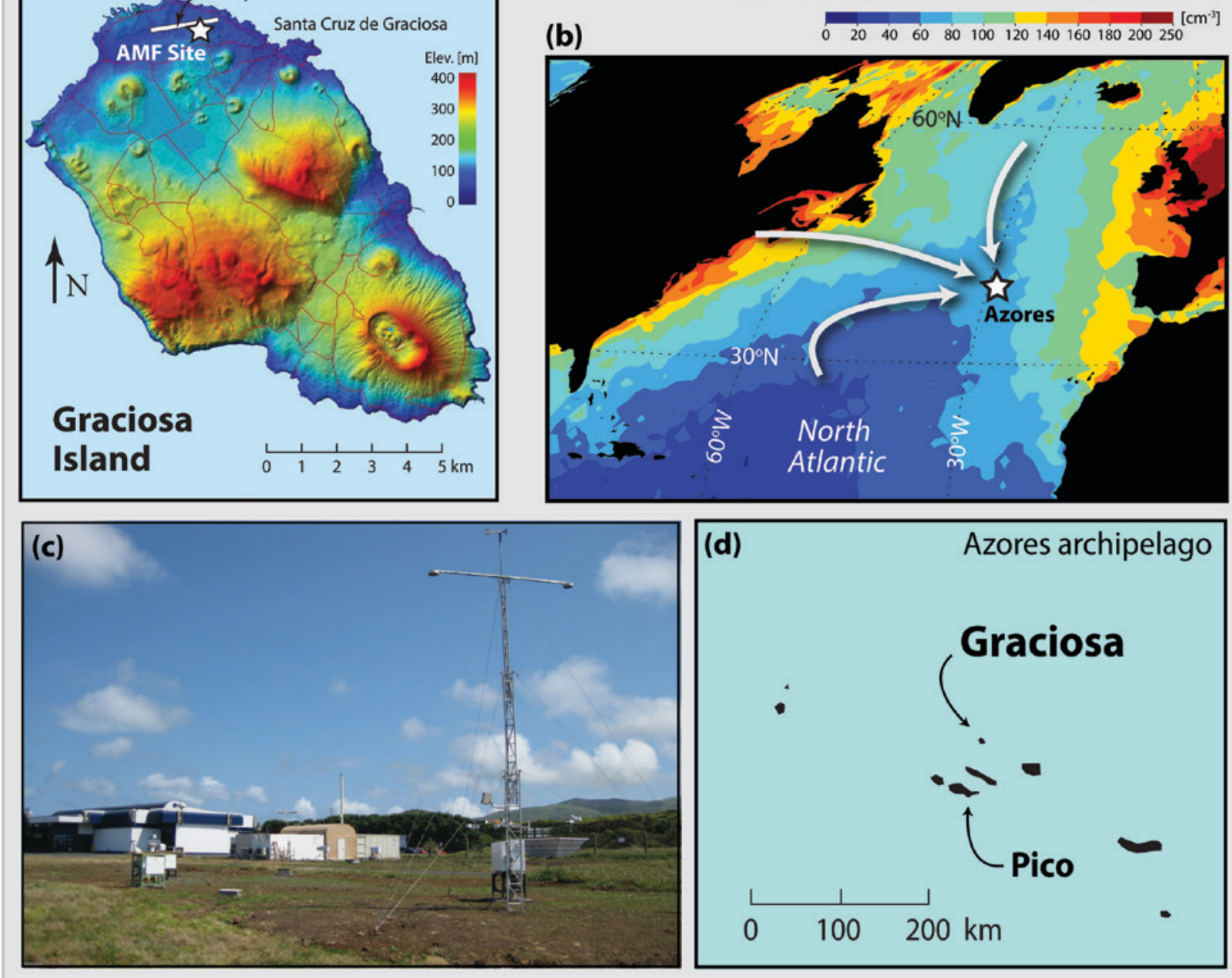

FIG. I. (a) Map of Graciosa Island showing terrain elevation and the location of the AMF site at the airport approximately $2 \mathrm{~km}$ west of the main town, Santa Cruz de Graciosa. (b) Map showing the location of the Azores in the North Atlantic. Colors show the annual-mean cloud droplet concentration for warm, overcast clouds as observed by the Moderate Resolution Imaging Spectroradiometer (MODIS) on the National Aeronautics and Space Administration (NASA) Terra satellite. The Azores receives a diverse range of air masses from North America, from the Arctic, and from northern Europe. (c) Photograph of the AMF site looking to the southeast. (d) Map of the location of Graciosa (and Pico) in the Azores Archipelago.

TABLE I. The primary science questions addressed during CAP-MBL.

- Which synoptic-scale features dominate the variability in subtropical low clouds on diurnal to seasonal time scales over the northeast Atlantic?

- Do physical, optical, and cloud-forming properties of aerosols vary with the synoptic features?

-What is the variability in precipitation frequency and strength in the subtropical cloud-topped MBL on diurnal to seasonal time scales, and is this variability correlated with variability in aerosol properties?

- Can we find observational support for the Twomey effect in clouds in this region?

- Are observed transitions in cloud mesoscale structure (e.g., from closed cellular to open cellular convection) influenced by the formation of precipitation?

- How well can state-of-the-art weather forecast and climate models (run in forecast mode) predict the day-to-day variability of cloud cover and its radiative impacts? 
all situated at the airport on the northern, low-lying side of the island. Of all the instruments, perhaps most important for CAP-MBL are the $95-\mathrm{GHz}$ radar, the ceilometer, and the microwave radiometer which together provide critical information on cloud boundaries, light precipitation, and condensate amounts. The frequent soundings provide important information about marine boundary layer (MBL) structure needed for model evaluation and to initialize process models. The cloud condensation nucleus counter, which is part of the ARM Aerosol Observing System, is a critical measurement to provide constraints on the different aerosol influences on clouds. Figure 1 shows the location of the measurements on Graciosa and the broader Azores Archipelago. In addition, during summer 2010, a small radiation platform was deployed at a trace-gas site established by the National Oceanic and Atmospheric Administration (NOAA) close to the summit of the volcanic island of Pico (elevation $2350 \mathrm{~m}$ ) some $60 \mathrm{~km}$ south of Graciosa (see, e.g., Honrath et al. 2004). This suite included a Multifilter Rotating Shadowband Radiometer

TABLE 2. Key AMF remote sensing instrumentation deployed during the CAP-MBL deployment of the ARM Mobile Facility at Graciosa from Apr 2009 to Dec 2010.

\begin{tabular}{|c|c|c|c|}
\hline Instrument & Key derived parameters & Resolution/range & Availability \\
\hline $\begin{array}{l}\text { 95-GHz profiling radar } \\
\text { (WACR) }\end{array}$ & $\begin{array}{l}\text { i) Cloud and precipitation } \\
\text { vertical structure } \\
\text { ii) Cloud-top height } \\
\text { iii) Drizzle drop size distribution } \\
\text { using both Doppler spectral } \\
\text { measurements (Frisch et al. 1995; } \\
\text { Luke and Kollias 2013) and with } \\
\text { Vaisala ceiloemter below the } \\
\text { cloud base (O'Connor et al. 2005) }\end{array}$ & $\begin{array}{l}\text { Resolution: } 43 \mathrm{~m} \\
\text { Time: } 2 \mathrm{~s} \\
\text { Max range: } 15 \mathrm{~km}\end{array}$ & $\begin{array}{l}\text { Operational } 5 \text { Jun 2009-end } \\
\text { No data I-25 Sep } 2010 \text { [see } \\
\text { Rémillard et al. (20I2) for } \\
\text { sampling statistics] }\end{array}$ \\
\hline $\begin{array}{l}\text { Vaisala Ceilometer (VCEIL) } \\
\text { and MPL }\end{array}$ & $\begin{array}{l}\text { i) Cloud-base height } \\
\text { ii) Cloud cover } \\
\text { iii) Precipitation profiling below } \\
\text { the cloud base (with radar) } \\
\text { iv) Cloud visible optical } \\
\text { thickness in all-sky conditions }\end{array}$ & $\begin{array}{l}\text { Resolution: } 15-30 \mathrm{~m} \\
\text { Time: } 30-60 \mathrm{~s} \\
\text { Max range: } \sim 5 \mathrm{~km}\end{array}$ & $\begin{array}{l}\text { VCEIL operational I3 Apr } \\
\text { 2009-end } \\
\text { MPL operational II Apr } \\
\text { 2009-end [see Rémillard et al. } \\
\text { (2012) for sampling statistics] }\end{array}$ \\
\hline $\begin{array}{l}\text { Microwave radiometer: } \\
23 / 31 / 90 \mathrm{GHz}\end{array}$ & $\begin{array}{l}\text { i) Cloud liquid water path } \\
\text { ii) Column water vapor path }\end{array}$ & Time: $20 \mathrm{~s}$ & $\begin{array}{l}\text { Operational } 27 \text { Apr 2009-end } \\
\text { [see Rémillard et al. (2012) for } \\
\text { sampling statistics] }\end{array}$ \\
\hline Radar wind profiler (RWP) & $\begin{array}{l}\text { i) Horizontal wind profiles } \\
\text { ii) Virtual temperature profiles }\end{array}$ & Time: $6 \mathrm{~min}$ & Operational I May 2009-end \\
\hline $\begin{array}{l}\text { Visible spectral radiometers: } \\
\text { MFRSR, } \\
\text { Narrow field-of-view (NFOV), } \\
\text { and Sunphotometer }\end{array}$ & $\begin{array}{l}\text { i) Cloud visible optical } \\
\text { thickness: used to infer cloud } \\
\text { microphysical properties (droplet } \\
\text { concentration, effective radius) in } \\
\text { combination with MWR } \\
\text { ii) Aerosol optical properties in } \\
\text { clear skies }\end{array}$ & Time: $20 \mathrm{~s}$ (MFRSR) & $\begin{array}{l}\text { MFRSR operational } 5 \text { May } \\
\text { 2009-end } \\
\text { NFOV operational } 20 \text { Aug } \\
\text { 2009-end } \\
\text { Sunphotometer operational } \\
\text { I May 2009-18 Apr 20II }\end{array}$ \\
\hline $\begin{array}{l}\text { Atmospheric Emitted Radiance } \\
\text { Interferometer (AERI) }\end{array}$ & $\begin{array}{l}\text { Cloud LWP estimates for thin } \\
\text { clouds [combined with MWR, } \\
\text { following Turner (2007)] }\end{array}$ & $\begin{array}{l}\text { Spectral: } 3-19.2 \mu \mathrm{m} \\
\text { with } 3.3-36-\mathrm{nm} \text { resolution } \\
\text { Time: } 6 \mathrm{~min}\end{array}$ & $\begin{array}{l}\text { Operational Apr-Jun } 2009 \\
\text { and Dec 2009-Dec } 2010\end{array}$ \\
\hline Broadband radiometers & $\begin{array}{l}\text { Downwelling shortwave and } \\
\text { longwave radiative fluxes used } \\
\text { to constrain the surface energy } \\
\text { budget }\end{array}$ & Time: I min & Operational I5 Apr 2009-end \\
\hline Total sky imager (TSI) & Cloud coverage and type & Time: $30 \mathrm{~s}$ & $\begin{array}{l}\text { Operational } 14 \text { Apr } 2009-\text { end } \\
\text { when solar elevation }>5^{\circ}-10^{\circ}\end{array}$ \\
\hline
\end{tabular}


(MFRSR) and broadband shortwave and longwave radiometers. The scientific objective of this deployment was to measure the radiative fluxes and aerosol optical thickness above the marine boundary layer clouds and thereby provide a constraint that could be used in conjunction with surface radiation measurements at Graciosa to directly measure the cloud optical thickness in broken cloud fields.

The surface and in situ measurements are complemented by analyses of 3-km Meteorological Satellite- 9 (Meteosat-9) hourly images from the Spinning Enhanced Visible and Infrared Imager (SEVIRI) instrument using the visible-infrared-shortwaveinfrared split window technique (see Minnis et al. 2011) over a domain bounded by $33^{\circ} \mathrm{N}, 43^{\circ} \mathrm{N}, 23^{\circ} \mathrm{W}$, and $33^{\circ} \mathrm{W}$. The SEVIRI analyses yield a variety of cloud and radiative properties including cloud cover, liquid water path, optical thickness, effective radius, and cloud-top temperature and height (Minnis et al. 2008).

\section{CLOUD AND METEOROLOGICAL} VARIABILITY. The specific CAP-MBL science questions (Table 1) include two focused on the impact of synoptic and seasonal variability on clouds and aerosols. To begin to address these, we note a marked seasonality in the surface pressure patterns near Graciosa (Figs. 2a,b). The winter season exhibits a strong meridional gradient of surface pressure between the semipermanent Icelandic low and the Azores high (Fig. 2a). Surface winds are predominantly from the southwest in January (Fig. 2c). The large values of the standard deviation of the $500-\mathrm{hPa}$ geopotential height over this region indicate a substantial amount of variability in the winter-season storm track (Fig. 2a). Graciosa is usually either in the southern portion or to the south of individual winter-season midlatitude cyclone tracks. This is reflected in the satellite cloud fraction data, which show a seasonal peak in total cloud fraction in the winter (Fig. 2e).

During summer, the Icelandic low disappears and the Azores high pressure system strengthens (Fig. 2b), leading to reduced high and overall cloud cover (cf. Figs. 2e,f and 3) and an increased prevalence of fair

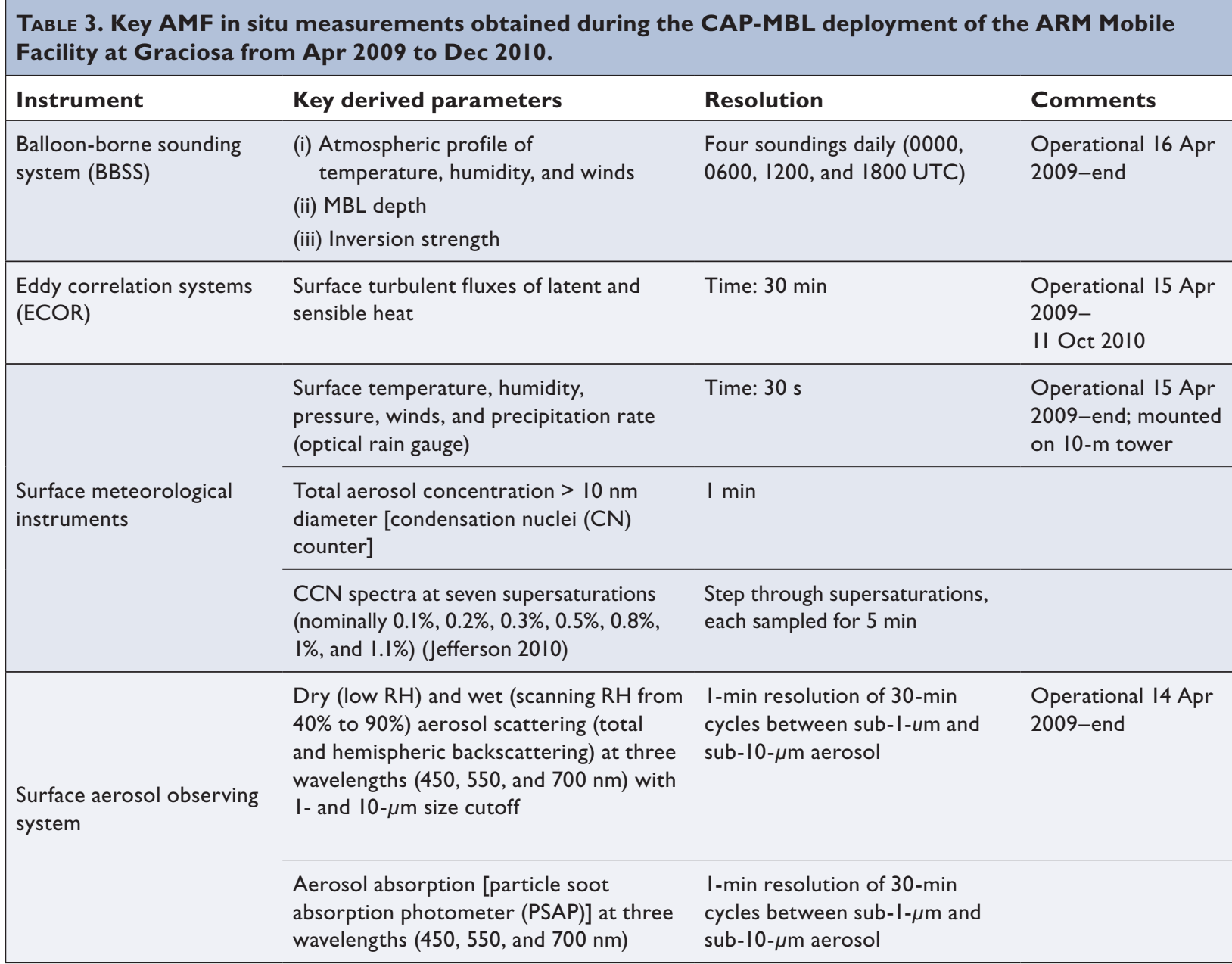




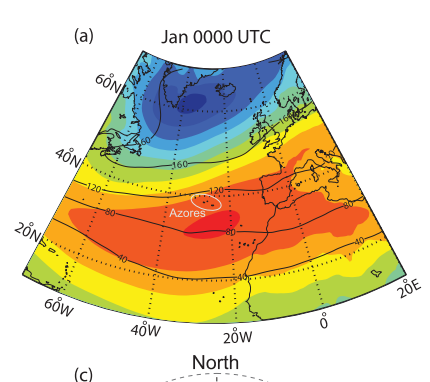

(c)

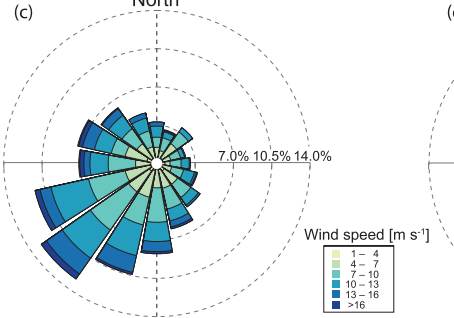

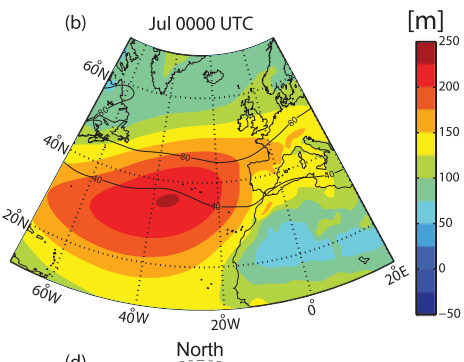

(d)
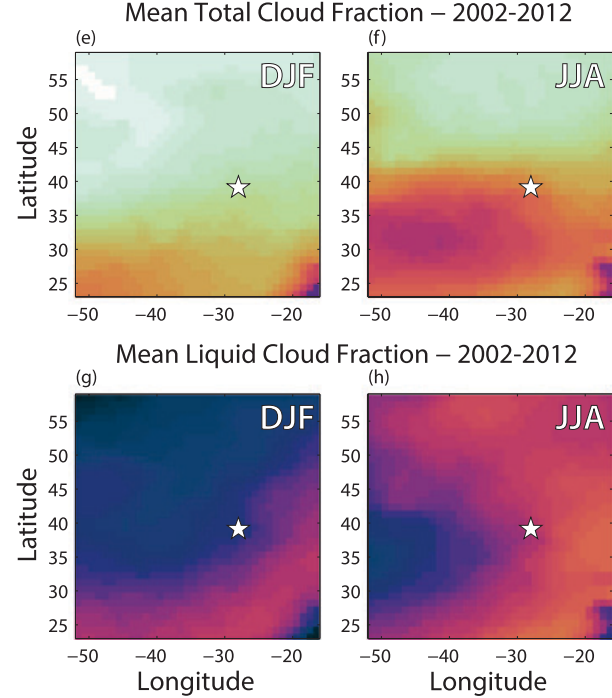

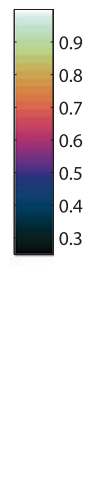

Fig. 2. Mean 1000-hPa geopotential heights (color-filled contours) for (a) Jan and (b) Jul generated from the 0000 UTC ECMWF interim reanalysis (ERA-Interim) fields (Dee et al. 20II). Contours of the standard deviation of the $500-\mathrm{hPa}$ geopotential heights $(\mathrm{m})$ are overlaid to indicate variability in the storm track. Surface wind roses for (c) Jan and (d) Jul. Maps of MODIS mean (e),(f) total and (g),(h) liquid phase cloud fraction for the (e),(g) Dec-Feb (DJF) and (f),(h) Jun-Aug (JJA) seasons. Cloud fraction is derived on $I^{\circ} \times 1^{\circ}$ areas averaged over each 3-month season for the years 2002-12 using the collection 5I Aqua MODIS cloud phase infrared day histogram counts product. Day and night observations are combined. The star in the cloud fraction panels denotes the location of Graciosa Island. A $3 \times 3$ pixel median smoothing filter was applied to the data to remove orbit swath edge sampling artifacts.
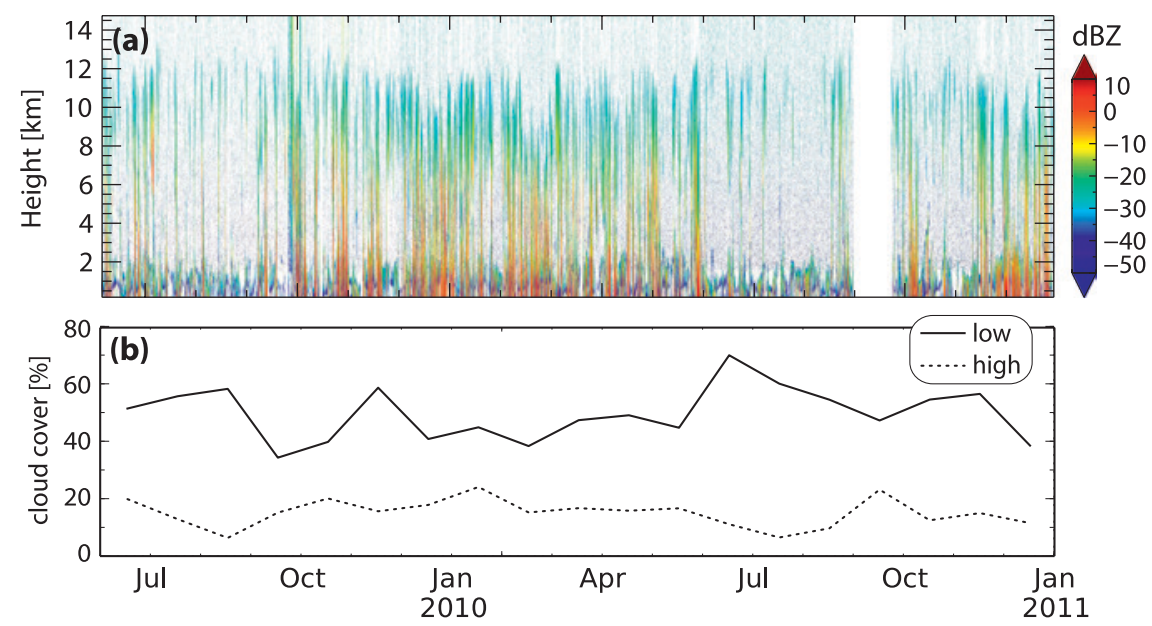

FIG. 3. (a) Height-time series of vertically pointing W-band radar reflectivity for the entire deployment. Radar data for much of September 2010 are missing. (b) Monthly low and high cloud cover determined using the W-band ARM Cloud Radar (WACR) and ceilometer dataset, as described in Rémillard et al. (2012).

weather conditions. Surface wind speeds in July are weaker than in winter and the wind direction ranges from southwesterly to northeasterly (Fig. 2d), depending upon the exact position of the Azores high. The prevalent surface high pressure conditions are associated with substantially reduced variability in the 500-hPa geopotential height, implying that synoptic intrusions from high latitudes are far less frequent (Fig. 2b).

Figure 3 a shows a timeheight cross section of reflectivity from the vertically pointing $\mathrm{W}$-band radar for the entire campaign, showing the range of conditions as a result of synoptic and seasonal variability. Strong reflectivity at low levels, indicative of significant precipitation, tends to occur during October to May and is often associated with relatively deep systems, in some cases extending all the way to the tropopause. Interestingly, the seasonal cycle in the height of the tropopause is strikingly evident. Low clouds are common through the entire year with an annual average coverage of approximately 50\% (Rémillard et al. 2012; Dong et al. 2014a). The primary modulation of the seasonal cycle of overall cloudiness is driven by different synoptical systems (Rémillard et al. 2012; Dong et al. 2014a). 
Despite slightly fewer low clouds during summer [more low liquid clouds are observed from space during summer (Figs. 2g,h) because of the reduced masking by high clouds], wintertime low clouds are frequently associated with deeper synoptic systems, and so the incidence of fair weather low clouds (stratocumulus and cumulus with no clouds above) is greatest in summer when the static stability is greatest (Rémillard et al. 2012; Dong et al. 2014a). This makes the less disturbed summertime environment a more useful time to focus on the key science goals of CAPMBL (Table 1), which will be easier to address when low clouds are exclusively present.

An analysis of the frequency of occurrence of different weather states derived through a cluster analysis of cloud property distributions [Fig. 4, based on Tselioudis et al. (2013)], indicates that the Azores experience the range of different weather states with a similar frequency to that experienced globally. The Azores experience the low-cloud weather states somewhat more frequently than the planet as a whole with fewer instances of clear skies and fair weather conditions and more frequent occurrences of trade cumulus and stratocumulus, and this probably reflects the marine environment. The Azores also experience a range of middle- and high-level clouds that do not occur frequently in other stratocumulus regions, highlighting the complexity of the meteorological influences on clouds in the region. This is a result of the location of the Azores in the transition between the subtropical and midlatitude dynamic regimes, which also makes the location a particularly useful one to both study cloud changes in such dynamical transitions and test the ability of models ranging from cloud-resolving models to global climate models (GCMs) to simulate those cloud changes.

Although an excellent site for studying low clouds, Graciosa experiences a much greater degree of meteorological variability than is found in the subtropical stratocumulus sheets and the tropical trades that have been the subject of much recent research (e.g., Rauber et al. 2007; Mechoso et al. 2014).
This is exemplified by a common meteorological metric called the estimated inversion strength (EIS), which is a bulk measure of the strength of the boundary layer capping inversion based on the average static stability between the surface and $700 \mathrm{hPa}$ (Wood and Bretherton 2006). Figure 5 compares histograms of EIS summer when the low-cloud amount peaks, as derived from CAP-MBL soundings with those from soundings taken from ships over the southeastern Pacific subtropical stratocumulus region during the peak low-cloud season (austral spring) during the Variability of American Monsoon Systems (VAMOS) Ocean-Cloud-Atmosphere-Land Study (VOCALS; de Szoeke et al. 2012). One can immediately see that during summertime Graciosa experiences a wider distribution of EIS values and a lower mean EIS than does the southeastern Pacific. There is actually very little overlap of the EIS distributions. The weaker inversions over Graciosa help explain why the low cloud cover during summer ( $50 \%$; Rémillard et al. 2012; Dong et al. 2014a) is significantly less than that over the southeastern Pacific. The weaker and more variable inversions are also manifested in a much greater spread in the heights of summertime boundary layer clouds during summer over Graciosa compared with the southeastern Pacific region during VOCALS (Fig. 6).

\section{AEROSOL AND CLOUD MICROPHYSICAL VARIABILITY AND AIRMASS ORIGINS. The}

Azores are influenced by a wide variety of air masses.

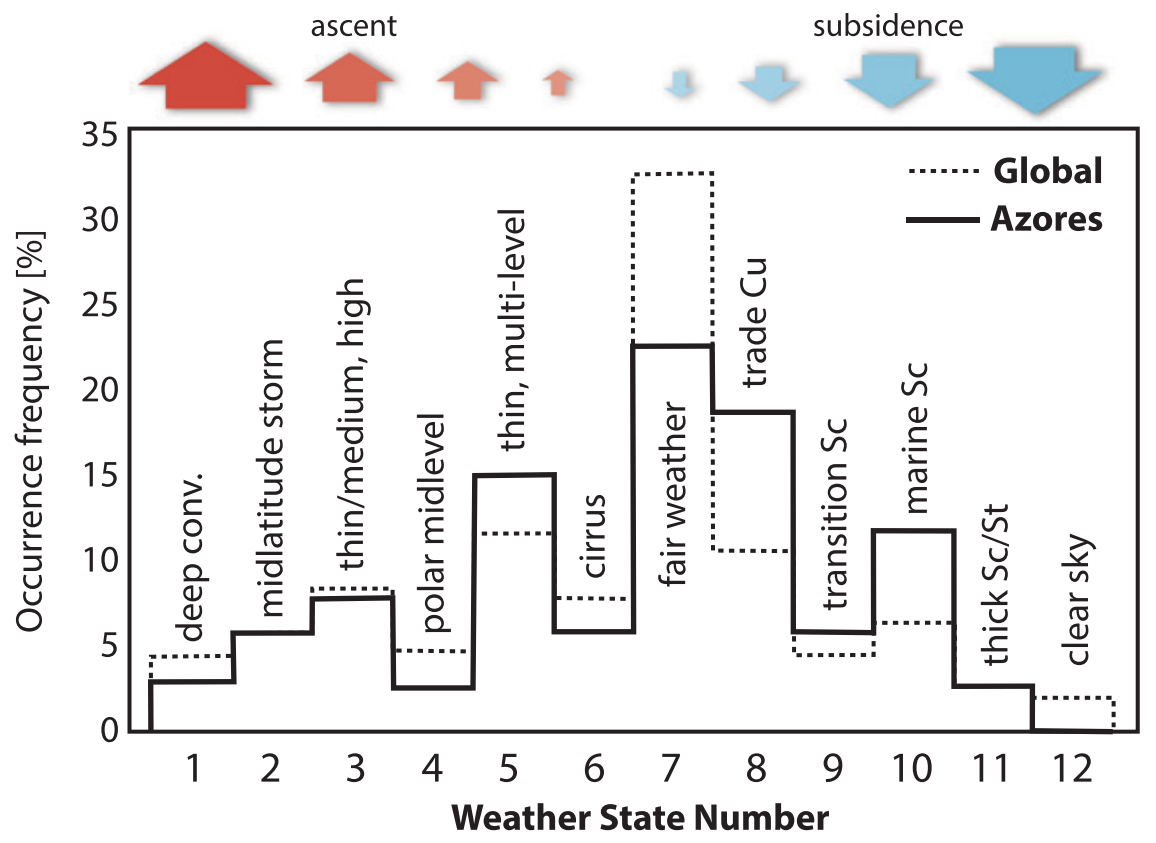

FIG. 4. Frequency of occurrence of different weather states determined using passive and active cloud sensors at the Azores (solid) and for the globe as a whole (dotted) (from Tselioudis et al. 2013). 


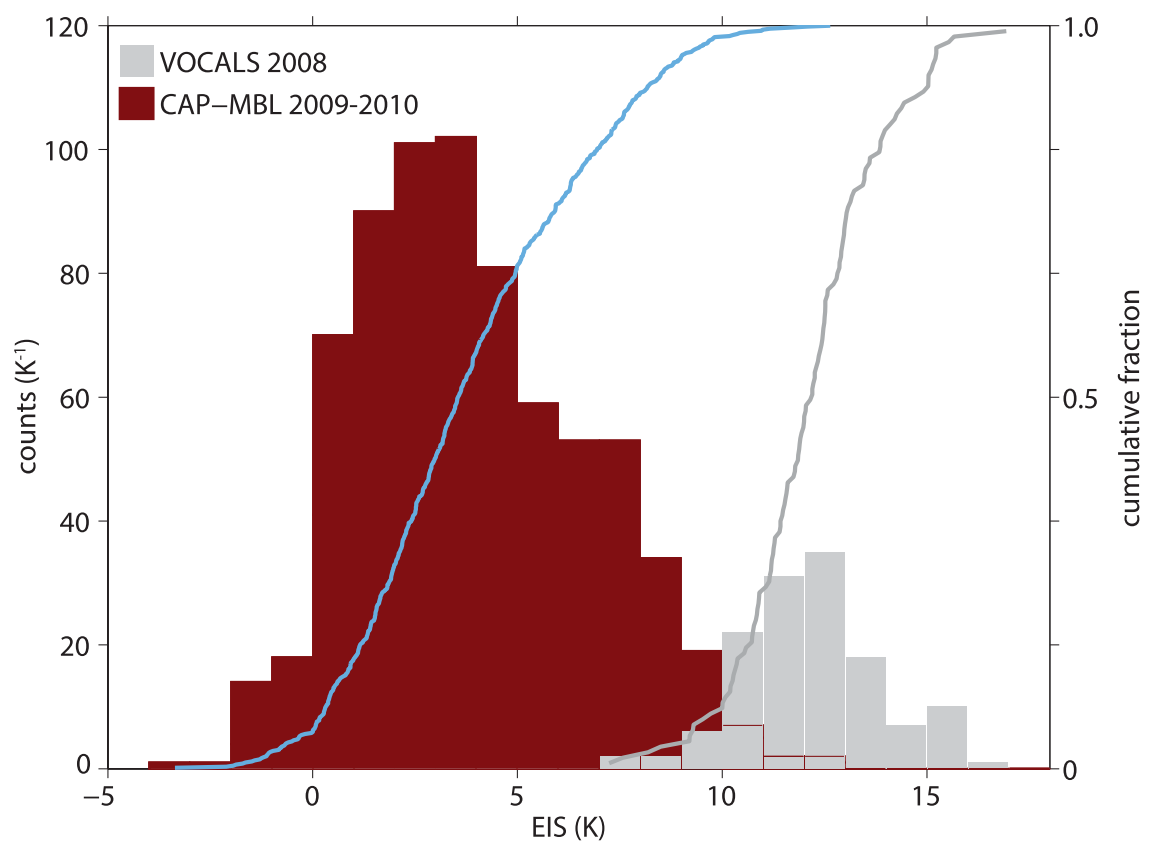

FIG. 5. Histogram counts of EIS (Wood and Bretherton 2006) in I-K bins from summertime (JJA) CAP-MBL 2009 and 2010 soundings (red bars) and VOCALS 2008 (Oct-Nov; gray bars). The right axis shows cumulative distributions of EIS for all of CAP-MBL (blue line) and VOCALS (gray line). concentration measured at a given time to a single source. That said, daily trajectories during summer 2009 (Fig. 7) are useful for revealing the diversity of air masses arriving at Graciosa, which predominantly have North American, subtropical Atlantic, and North Atlantic origins if traced back 10 days. This diversity yields strong variability in the concentration of cloud condensation nuclei (CCN). Some high CCN concentration events can be traced back to trajectories passing over industrialized regions of North America at low levels (Fig. 8b). Relatively high CCN concentrations indicative of pollution influence can even be found in air masses that,

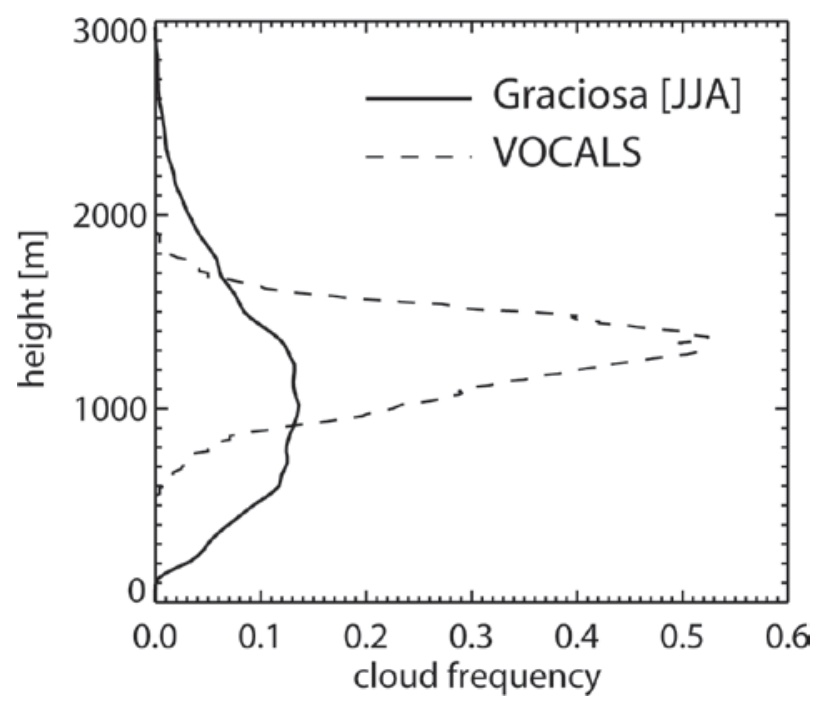

Fig. 6. Cloud occurrence frequency as a function of height for Graciosa during JJA (solid) and from the southeastern Pacific during the VOCALS field campaign (dashed; Burleyson et al. 20I3).

The subtropical lower troposphere largely experiences conditions of large-scale subsidence in which the MBL is continually being diluted by free-tropospheric (FT) air with a supply time scale of several days. The surface air therefore typically includes particles that have been entrained into the MBL over several days. It is therefore challenging to attribute the aerosol according to trajectory analysis, have been confined to the marine subtropical environment for the previous 10 days (Fig. 8a). This likely occurs because the MBL entrained significant layers of pollution from the FT during its excursion around the meandering subtropical high. Initial attempts to construct composite trajectories for different aerosol loadings have not been fruitful because such a diverse range of trajectories are found for any given loading. This indicates just how challenging it is to determine how the synoptic meteorological variability impacts aerosols (Table 1).

Besides synoptic-scale variability in aerosols at Graciosa, there are also interesting seasonal variations in cloud and aerosol microphysical properties that are observed with a number of different sensors. The CAP-MBL deployment provided the first opportunity for comprehensive characterization of the seasonal variability in aerosol and cloud microphysical properties in the Azores (Dong et al. 2014a and 2014b). Prior to this, it was known from gas phase measurements taken in the FT on Pico (Fig. 1d) that pollution and biomass burning aerosols from North America frequently reach the remote North Atlantic region (Honrath et al. 2004) with a distinct springtime maximum in the key indicator of combustion, carbon monoxide (Val Martin et al. 2008).

The seasonal cycle of cloud droplet concentration $\left(N_{c}\right)$ estimates (Fig. 9a) shows a spring/summer maximum and a minimum during winter, although 


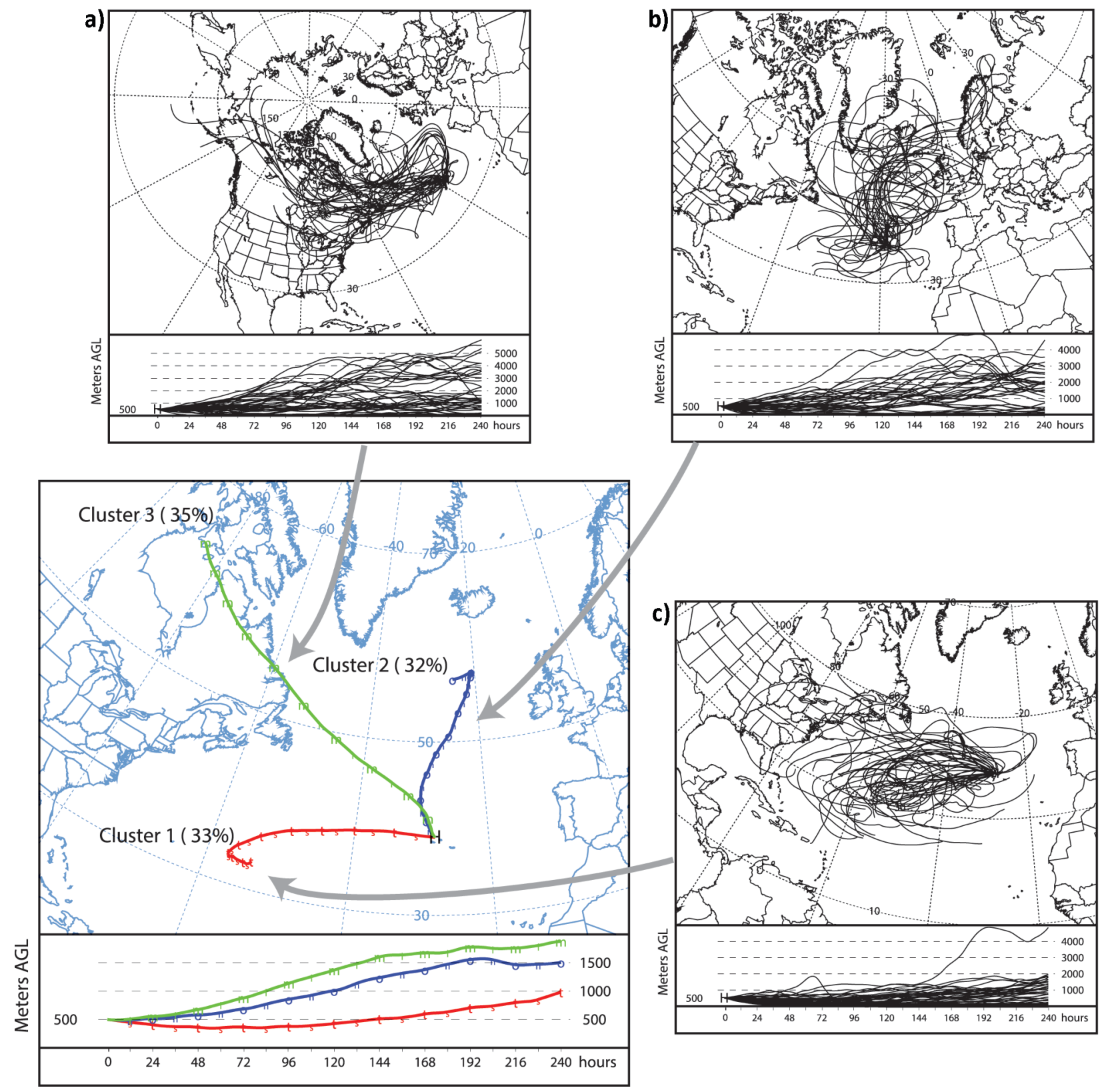

FIG. 7. Clusters of trajectories arriving at Graciosa during the summer period (May-Aug 2009) showing the three primary clusters representing (a) North American, (b) Arctic/northern European, and (c) recirculating Azores high flow. The Hybrid Single-Particle Lagrangian Integrated Trajectory (HYSPLIT) IV model (Draxler 1999) was employed and 10-day back trajectories ending at Graciosa $\mathbf{5 0 0} \mathrm{m}$ above mean sea level were run every day for Apr-Sep 2009. NCEP Global Data Assimilation System (GDAS) meteorological data including model vertical velocity are used to determine the trajectory motion. A cluster analysis was then performed on the resulting back-trajectory set (e.g., Toledano et al. 2009) and a three-cluster solution was found to capture most of the variance.

different estimates yield somewhat different annual cycles, an issue that needs further assessment by direct comparison of retrievals for individual cases and by comparison with in situ data from aircraft. It is encouraging that all three $N_{c}$ estimates have similar annual-mean values and that the $N_{c}$ cycle agrees qualitatively with the annual cycle of CCN concentration, especially at low supersaturations (Fig. 9b). This provides some preliminary evidence that the key processes involved in the Twomey effect are in operation in these clouds, which is one of the key scientific questions of CAP-MBL (Table 1). Determining the exact annual cycle of $N_{c}$ using surface and satellite remote sensing requires a 
longer data record than is available from CAP-MBL and a more systematic comparison between different retrieval approaches than has been attempted thus far.
There are well-defined springtime peaks in submicron aerosol scattering (Fig. 9c) and aerosol optical depth (AOD) at Graciosa during CAP-MBL (Fig. 9d).

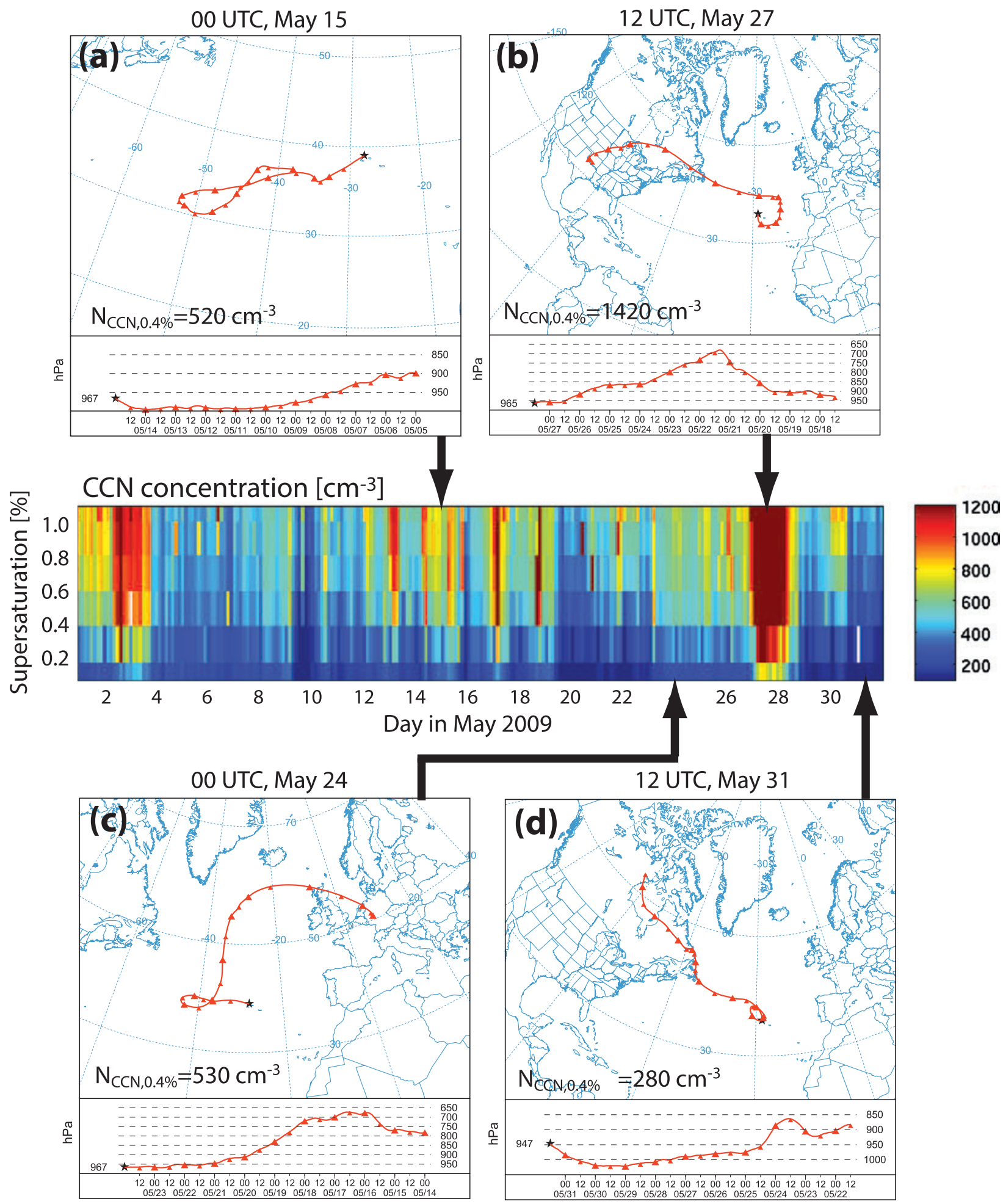

FIG. 8. (a)-(d) Four examples of I0-day airmass back trajectories (see Fig. 7 caption for details) arriving at Graciosa during May 2009, reflecting characteristic air masses. Each of the four panels show the trajectory map (top) and height (bottom) with ticks every $12 \mathrm{~h}$. (middle) CCN supersaturation spectra time series measured at Graciosa during the same month. 
Boreal spring favors transport from industrialized continental areas because of strong zonal westerlies and increased lofting of pollutants by cold fronts extending southward from midlatitude cyclones (Liang et al. 2004; Zhao et al. 2012). Although transport from continents is expected to be favored during the spring months, a picture consistent with the spring maximum in carbon monoxide (CO; Fig. 9d) there is also the possibility that reduced precipitation sinks during summertime also help to control the seasonal variability. Springtime aerosol maxima have also been observed over the Pacific at Mauna Loa (Bodhaine 1996; Andrews et al. 2011), and modeling studies indicate peak zonal intercontinental aerosol transport during boreal springtime at all longitudes (e.g., Zhao et al. 2012). Aerosol extinction profiles derived from micropulse lidar (MPL) during CAP-MBL show that the excess aerosol scattering in spring at Graciosa is confined below approximately 1-km altitude (Kafle and Coulter 2013). Supermicron aerosol scattering (difference between total and submicron scattering) exceeds the submicron scattering by a factor of 2-5 (Fig. 9c), with the greatest scattering during winter and spring, broadly consistent with greater sea salt aerosol flux as wind speed increases (Figs. 2c,d).

Although the lack of enhanced FT scattering during springtime could lead one to conclude that long-range transport is not responsible for the springtime maxima in aerosol loading at Graciosa, it is important to point out that free-tropospheric aerosols are typically smaller than those in the PBL and so their scattering signature is relatively weak and falls below the detection limit for spaceborne and most surface lidars. Despite this, when these particles are entrained into the PBL they grow because of aqueous phase deposition of sulfur species and they grow

FIG. 9. Composite seasonal cycles (using all available data) of (a) cloud droplet concentration retrieved using the transmitted solar irradiance and microwave radiometer (MWR) LWP (squares; Dong et al. 1998), from the MPL solar background light (Chiu et al. 2007) and MWR (black line) and from MODIS (red line; $I^{\circ} \times I^{\circ}$ box encompassing Graciosa, for all years: 200I-10; Platnick et al. 2003). (b) Surface CCN concentrations at four supersaturations. (c) Aerosol total and submicron dry extinction. Boxes span the 25 th and 75 th percentiles of the data with red bars indicating medians and the crosses indicating means. (d) Monthly-mean aerosol optical depth and $25 \mathrm{th}, 50 \mathrm{th}$, and 75 th percentile values from the Cimel sunphotometer (red) and mean values from MODIS (black). The composite seasonal cycle of carbon monoxide measured at the Pico mountain station from 2002 to 2005 is also shown (see Val Martin et al. 2008). hygroscopically because of the high relative humidity in the boundary layer compared with the FT (Clarke et al. 2013). Aerosol single scattering albedo measurements during CAP-MBL (not shown) indicate that aerosols are more absorbing during springtime, consistent with the idea that combustion aerosols from North America are potentially influential on the remote Atlantic during this season (Logan et al. 2014).

PRECIPITATION AT GRACIOSA. Understanding the factors controlling precipitation, especially

(a) Cloud droplet concentration

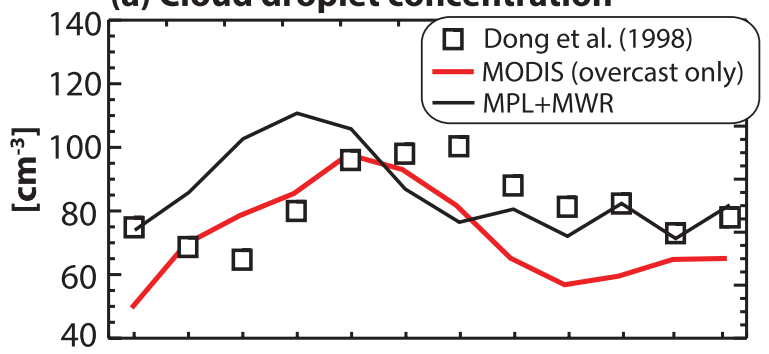

(b) CCN concentrations

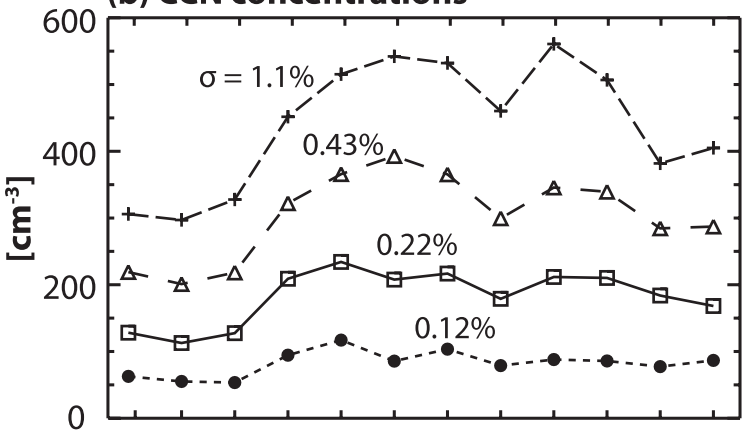

(c) Aerosol scattering coefficient

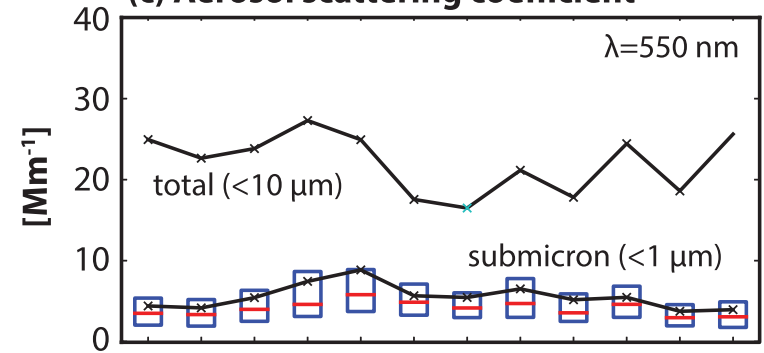

(d) Aerosol optical depth

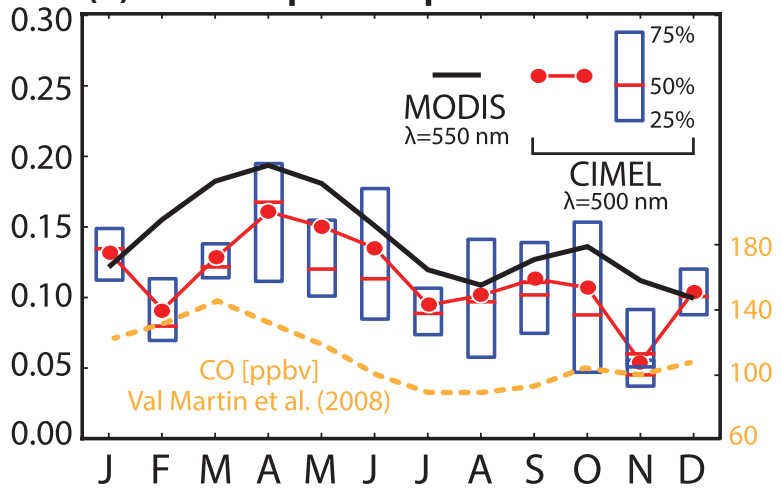


precipitation falling from clouds in the $\mathrm{MBL}$, is one of the main scientific questions being addressed by CAPMBL (Table 1). Remarkably, the W-band radar shows that detectable precipitation echoes are present below the cloud base for approximately half of all clouds at Graciosa (Rémillard et al. 2012). The near ubiquity of precipitation at the site is surprising given that the clouds are typically thin and often contain quite low condensate amounts. Precipitation at Graciosa is associated with clouds of all altitudes (Figs. 10a,b) such that clouds with top heights between 1 and $11 \mathrm{~km}$ all contribute roughly equally to surface precipitation in the annual mean. Even though low clouds produce relatively weak surface precipitation, they occur in sufficient quantity (Fig. 10c) that their precipitation is climatologically important. In summertime,
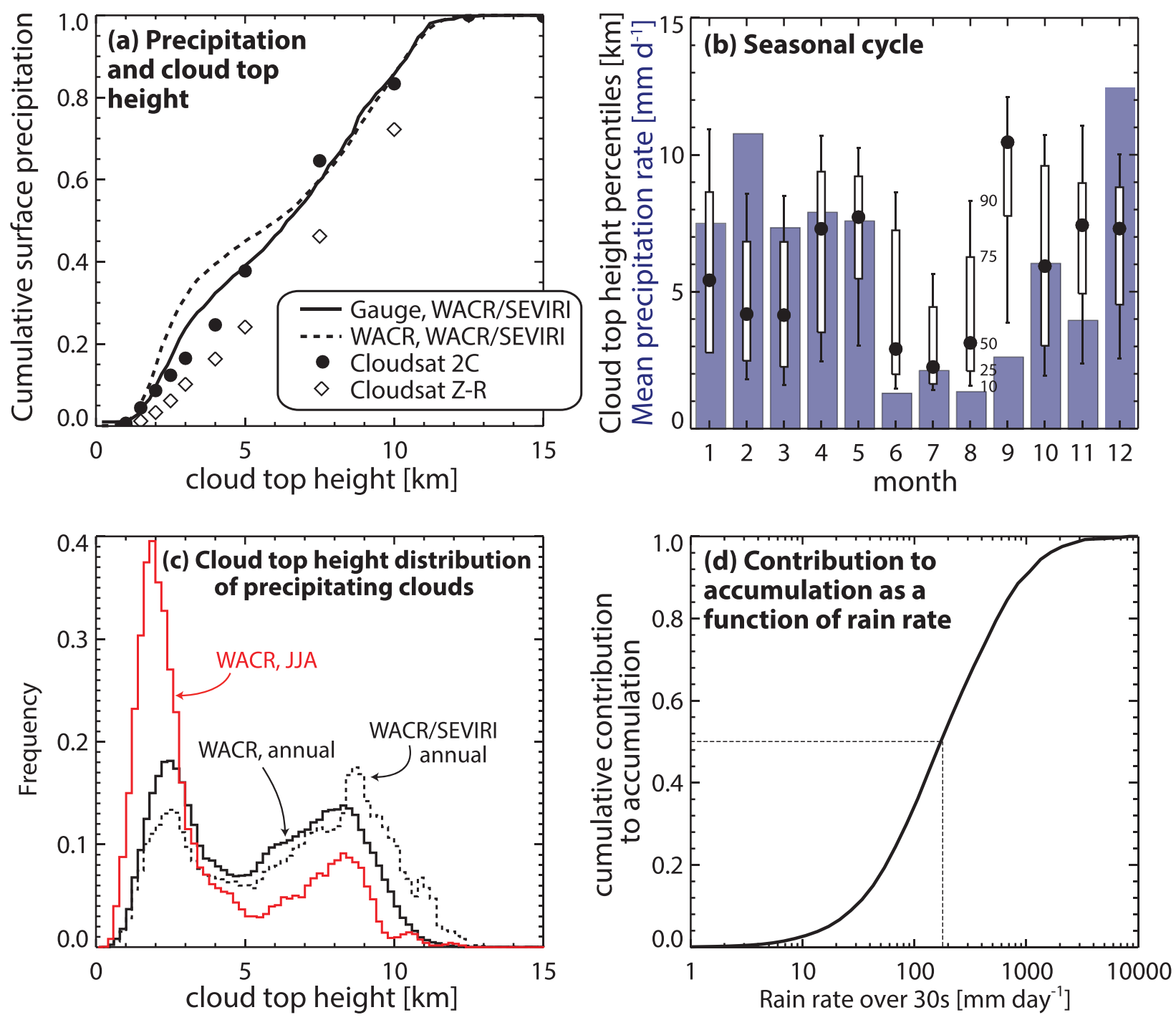

FIG. 10. Characteristics of precipitation reaching the surface at Graciosa. (a) Cumulative contribution to surface precipitation accumulation from clouds with tops exceeding the value shown on the abscissa, using different approaches. The solid line shows precipitation determined by the rain gauge and cloud-top height estimated with W-band ARM cloud radar (WACR) for columns that are not completely attenuated and satellite-determined IR cloud-top height from SEVIRI for attenuated columns. Filled circles are from CloudSat. (b) Composite seasonal cycle of precipitation from $2 \mathrm{I}$ months of the deployment (blue bars) and the cloud-top height corresponding to percentiles of total precipitation accumulation. For example, the filled circles indicate the cloud-top height for which $\mathbf{5 0 \%}$ of the total precipitation is associated with shallower clouds. (c) Cloud-top height distributions corresponding to 30 -s periods where the surface precipitation exceeds $10 \mathrm{~mm}^{-1 a{ }^{-1}}$. The black solid line shows cloud tops from the WACR only and the dotted line shows those from WACR-SEVIRI merged, both for annual data. The red curve shows the corresponding plot for JJA. (d) Contribution to surface accumulation from precipitation rates exceeding the abscissal value. 
most precipitating clouds have tops lower than $5 \mathrm{~km}$ (Figs. 10b,c). Approximately $20 \%$ of the surface precipitation $\left(\sim 1 \mathrm{~mm}\right.$ day $^{-1}$ out of an annual mean of $\sim 5 \mathrm{~mm} \mathrm{day}^{-1}$ ) originates from clouds with tops below $3 \mathrm{~km}$ (Fig. 10a). During the months of June-August, clouds with tops below $4 \mathrm{~km}$ contribute more than half of all surface precipitation (Fig. 10b); surprisingly, this is also the case in late winter. The cumulative contribution to precipitation as a function of quasiinstantaneous (30 s) rain rate (Fig. 10d) indicates that $20 \%$ of precipitation accumulation is associated with conditional precipitation rates lower than $\sim 3 \mathrm{~mm} \mathrm{~h}^{-1}$. An accurate accounting of the precipitation climatology at Graciosa must therefore include light precipitation from relatively shallow cloud systems.

\section{INTERACTIONS BETWEEN CLOUDS, AEROSOLS, AND PRECIPITATION. A feature} of the CAP-MBL deployment is the ability to simultaneously observe clouds, aerosols, and precipitation and to understand how these variables interact with each other. Interactions are two way, with aerosols potentially impacting precipitation most likely via the suppression of warm rain (Albrecht 1989), but in turn aerosols are strongly scavenged by precipitation, even in the relatively weak drizzle from low clouds (Wood 2006; Duong et al. 2011). Indeed, climatological aerosol concentrations over the remote oceans may be determined by warm rain processes (Wood et al. 2012). The CAP-MBL deployment's continuous record allows for greater statistical reliability in the observed relationships between aerosols, clouds, and precipitation than is possible with aircraft but retains the advantages of in situ sampling of aerosol properties that are difficult to constrain with satellite data. That said, the Azores exhibit stronger synoptic variability than is found in the subtropical/tropical marine low-clouds regions, making the separation of aerosol effects on clouds from those caused by meteorological forcing somewhat more challenging than in other regions dominated by low clouds. Because the summertime is less synoptically variable and contains more single-layer low clouds than the winter (Dong et al. 2014a), it makes the summer a more productive starting point for analyses.

We illustrate a variety of aerosol-cloudprecipitation interactions using two case studies. First, we highlight a case where very low observed aerosol concentrations coincide with shallow, precipitating MBL clouds. Very low aerosol concentration events are a regular occurrence over the southeastern Pacific (Terai et al. 2014), where they tend to be associated with changes in the large-scale cloud morphology and particularly the occurrence of open mesoscale cellular convection, which frequently occurs in the form of pockets or rifts within otherwise overcast stratocumulus (Stevens et al. 2005; Wood et al. 2008). According to a satellite-derived climatology, open mesoscale cellular convection occurs approximately $15 \%$ of the time during periods free of high clouds at the Azores (Muhlbauer et al. 2014). Factors controlling the preferred mesoscale morphology and transitions between different types of morphology are one of the key CAP-MBL science questions (Table 1). Figure 11 shows a case where a rift of open cells advects over Graciosa on 8-9 August 2009. The passage is marked by reductions in CCN concentrations that are close to an order of magnitude (Fig. 11b). Ship tracks can be seen in the satellite image within the rift, a region where SEVIRI retrievals show cloud droplet effective radii exceeding $20 \mu \mathrm{m}$ (Fig. 11a). The ship tracks are also evident as lines of relatively small effective radius values in the rift (Fig. 11a). Immediately prior to the passage, clouds in the boundary layer were drizzling (Fig. 11e), although it is not clear if this precipitation influences the CCN concentrations in the rift itself. Strong aerosol depletion events have been observed in the tropics and subtropics (Clarke et al. 1998; Wood et al. 2008; Sharon et al. 2006; Petters et al. 2006) and in the Arctic (Mauritsen et al. 2011), with the likely cause in each case being precipitation scavenging. Strong CCN depletion events occur quite frequently at the Azores and typically occur under conditions of light southerly winds and weak warm advection. It is important that we better understand the factors controlling the clean marine background aerosol and its variability because climate model experiments show that the strength of the global aerosol indirect effect is strongly sensitive to the preindustrial aerosol conditions (Hoose et al. 2009; Ghan et al. 2013).

Figure 12 shows a case of overcast marine stratocumulus with variable precipitation over the course of four hours on 7 November 2010. CCN concentrations are fairly steady between 1245 and 1600 UTC. The cloud liquid water path (LWP) varies considerably and appears to be a primary modulator of the cloud-base precipitation rate including periods of virga as well as precipitation of several millimeters per day at its heaviest between 1300 and 1400 UTC. Interestingly, in the early part of the record shown in Fig. 12, the cloud droplet concentration and CCN levels are higher; so, despite LWP values of 100-200 $\mathrm{g} \mathrm{m}^{-2}$ between 1200 and 1300 UTC (similar to those between 1400 and 1500 UTC), little precipitation is falling. This is suggestive of a potential suppression of precipitation by increased aerosols as has 
been observed in other stratocumulus cloud regimes (Geoffroy et al. 2008; Sorooshian et al. 2010; Terai et al. 2012). Indeed, the entire CAP-MBL data record has been used to quantify the extent of this suppression (Mann et al. 2014), demonstrating the utility of the long AMF dataset for studying the influence of aerosols on precipitation.

CONFRONTING MODELS. A primary motivation for the Graciosa measurements is to facilitate the improvement of climate and weather forecast models (Table 1; Ahlgrimm and Forbes 2014). Other modeling groups are also making various uses of CAP-MBL data, as detailed in Table 4 .

The current skill of a few climate and weather forecast models in hindcasting clouds and aerosols at Graciosa is briefly analyzed below to illustrate the value of this approach for comparing with the current measurements and to frame the opportunities for future improvement of these models using more detailed analyses. The variety of clouds at Graciosa is a good test of the moist physical parameterizations in these models. In addition, precipitation and cloud processing can have major impacts on boundary layer aerosol concentration and size distribution. Hence, for models with prognostic aerosols, a meaningful comparison of the simulated aerosol with Graciosa observations requires a good simulation of the precipitation and cloud in the region.

Operational global weather forecasts using the European Centre for Medium-Range Weather Forecasts (ECMWF) and National Centers for Environmental Prediction (NCEP) Global Forecast System models were sampled at the nearest grid point to the Graciosa site at their native vertical resolution. Two GCMs, the Community Atmosphere Model, version 5 (CAM5) and the Geophysical Fluid Dynamics Laboratory (GFDL) Atmospheric Model, version 3.9 (AM3.9), were run in a hindcast mode (Phillips et al. 2004). Five-day global forecasts were initialized from daily 0000 UTC ECMWF analyses for 1 June30 November 2009 interpolated to the climate model (a) MODIS vis. Image, 1240 UTC, August 8

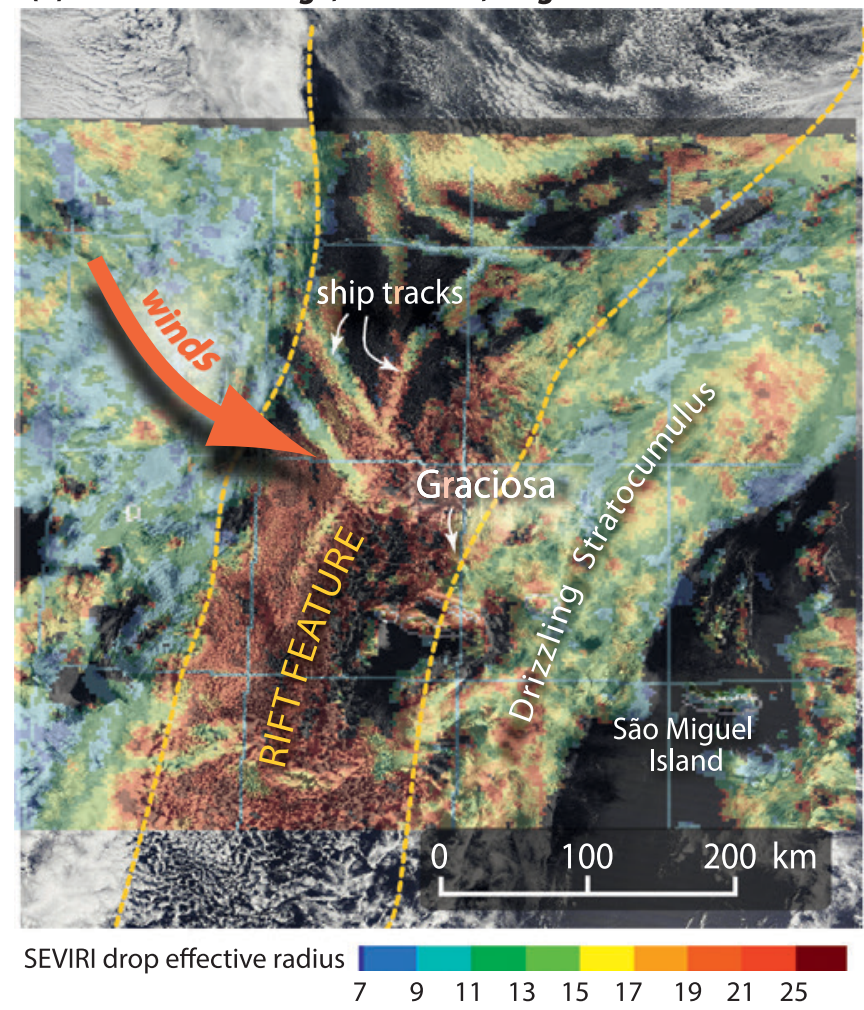

(b) CCN and total aerosol concentrations

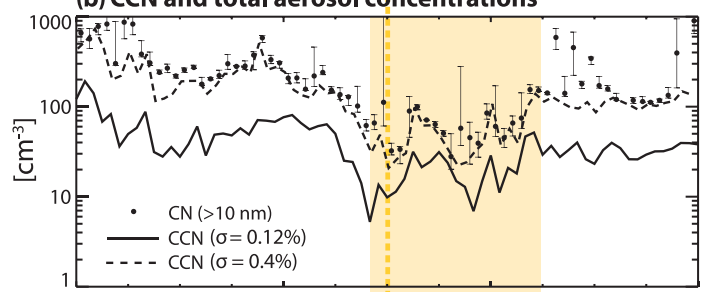

(c) Cloud fraction (-) drizzle fraction (---.-)

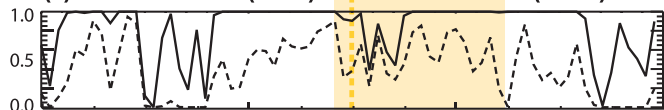

(d) Liquid water path
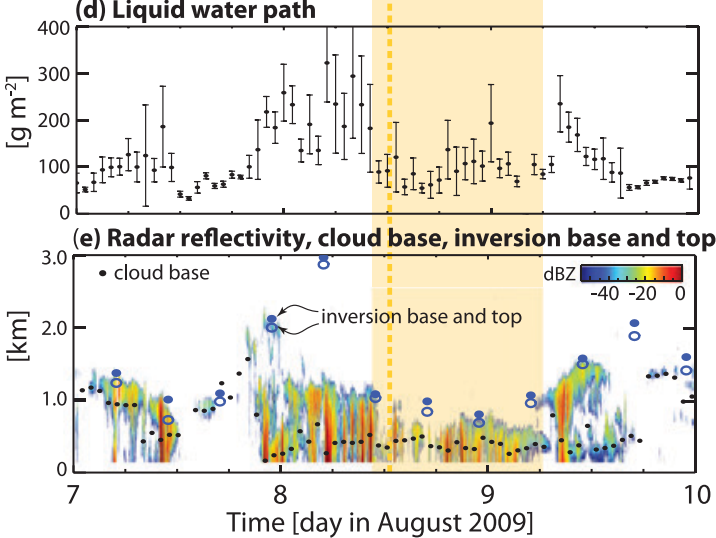

FIG. II. (a) MODIS visible image on 8 Aug 2009 (I240 UTC) showing rift feature containing small open cells and ship tracks in a shallow boundary layer about to cross Graciosa. Overlaid in transparency are the SEVIRI droplet effective radius retrievals showing especially large droplets in the rift. Time series (7-10 Aug) of (b) CCN concentrations at $0.12 \%$ and $0.4 \%$ supersaturation and total aerosol concentration, respectively; (c) fraction of time during each hour that clouds and drizzle are detected overhead; (d) liquid water path, with error bars indicating variability using standard deviation; and (e) radar reflectivity (colors), cloud base (black-filled circles), inversion base (blue open circles), and inversion top (blue-filled circles). 
grid. The ECMWF analyses were produced for the Year of Tropical Convection project at a resolution of $\sim 25 \mathrm{~km}$. The initial prognostic aerosol fields and land surface characteristics for each GCM forecast were carried over from the previous 24 -h forecast. To spin up these fields, daily hindcasts were also performed for the entire year prior to the forecasts. The results we present use 24-48-h forecasts, to avoid the initial spinup impacts from the ECMWF analysis.

Both climate models have much coarser horizontal grids than the weather forecast models. Only the ECMWF model has a grid fine enough to begin to resolve Graciosa Island itself. Hence, model errors in clouds and aerosols may arise not just from the simulated cloud and aerosol physics but also from errors in the small-scale circulations and island-scale flow.

The CAM5 and GFDL models both use prognostic aerosol schemes including representations of the interactions of clouds and aerosols. The ECMWF model also includes an aerosol transport scheme, but it is not allowed to affect the physical forecasts. The NCEP model does not include an aerosol scheme. We also did not archive accumulated precipitation or vertically resolved cloud cover from this model, so it could not be included in the plots below.

We analyze the simulated clouds and aerosols during a rainy month (November 2009) and a dry month (August 2009). Figure 13 compares the

TABLE 4. Modeling projects using AMF Azores datasets.

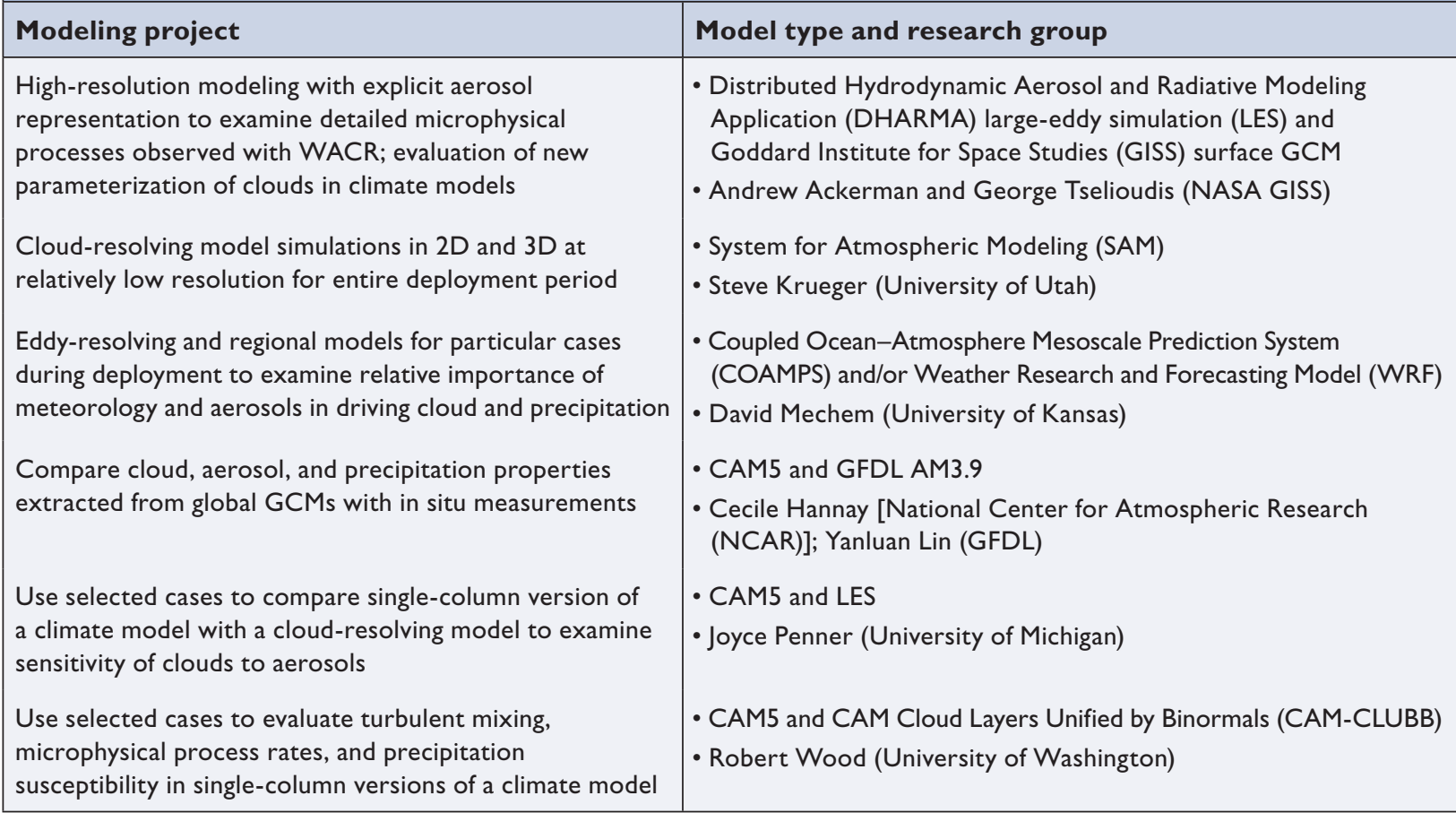



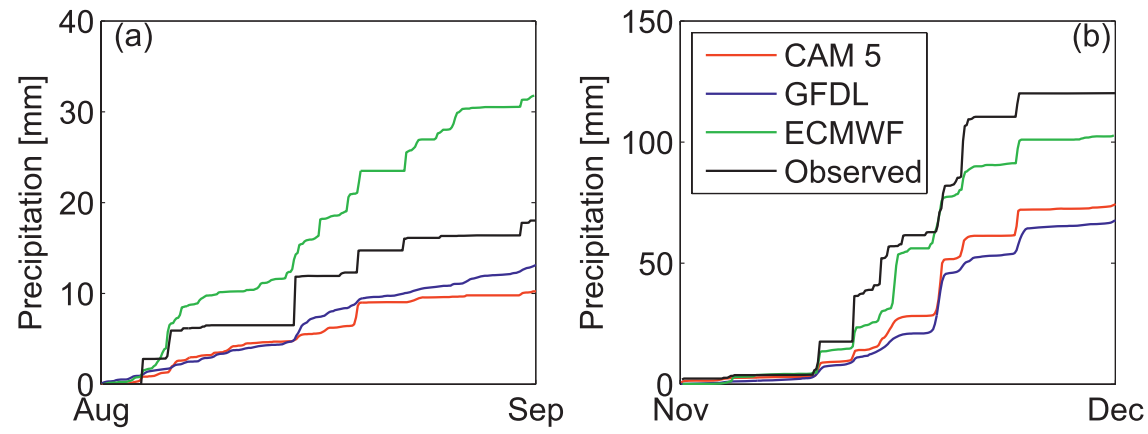

FIG. 13. Accumulated precipitation during the relatively dry month of Aug 2009 and the wetter month of Nov 2009. Black shows rain gauge measurements at the Graciosa AMF site, whereas the colors show model results interpolated to the site location from gridcell means.

accumulated precipitation over the course of each month observed by the AMF tipping-bucket rain gauge with that predicted by the 12-35-h ECMWF forecasts and the 24-48-h forecasts for the two GCMs. This is a necessarily imperfect comparison of a point measurement, possibly affected by the island terrain, with a gridcell-mean value. Nevertheless, all the models are able to predict which days will be relatively rainy, and their monthly accumulations lie within a factor of 2 of the observations. This suggests that they capture most of the synoptic-scale variability that might be expected to drive the day-to-day variations of clouds and aerosols and furthermore that hindcasts using the climate models with interactive aerosol have a chance of simulating the effects of precipitation scavenging on the aerosol population observed at Graciosa.

Figure 14 compares time-height sections of lower-tropospheric cloud cover simulated by the three models with the cloud boundary product derived from the AMF vertically pointing cloud radar and lidar. During both months, all three models skillfully distinguish shallow and deeper cloud regimes, though the AM3 cloud height appears less variable than observed during the dry month (August). The periods with cloud extending above $4 \mathrm{~km}$ usually correspond to rain events. These plots reiterate the potential for using a more in-depth comparison of global models with this dataset to improve their performance across a range of cloud types that is different than sampled at long-running midlatitude supersites in the United States and Europe.

Figure 15 compares aerosol sampled at ground level at Graciosa with that simulated by the two climate models. The daily-mean CCN concentration at a supersaturation of $0.1 \%$ is shown, which we showed earlier (Figs. 9a,b) is a reasonable proxy for the boundary layer cloud droplet concentration. The models, like the observations, show higher mean CCN in August than December, though both models tend to overestimate CCN on average. During each of the two months shown, the observed CCN concentration varies by an order of magnitude, and the models show similar overall levels of variability. The temporal correlation coefficients of daily-mean $\log (\mathrm{CCN})$ between the models and the observations are positive for both models during both months. However, they are not very large. Given $N=$ 30 daily values, with estimated 1-day lagged autocorrelation of $r_{1}=0.65$ for the models and $r_{1}=0.4$ for the observations, the effective number of independent samples per month is

$$
N_{*}=N\left(1-r_{1} r_{2}\right) /\left(1+r_{1} r_{2}\right)=18
$$

(Bretherton et al. 1999). With this sample size, the correlation coefficient between a model and the observations must exceed 0.4 to be significant at $95 \%$ confidence using a one-sided test; each model exceeds this level in one of the two analyzed months.

Overall, we conclude that the tested global models are simulating strong precipitation events and the time-varying vertical cloud distribution at Graciosa fairly well, but aerosol concentrations less skillfully. This suggests room for improvement in the parameterization of aerosol processing by clouds or in marine aerosol sources or errors in long-range aerosol transport. By focusing on particular events, the Graciosa measurements should be useful for separating these sources of error to provide information specific enough to stimulate improvement of model simulations of aerosol, cloud, and precipitation in remote marine regions.

SUMMARY AND FUTURE WORK. The observations collected during the 21-month CAP-MBL deployment of the AMF on Graciosa Island in the Azores comprise the longest dataset of its type collected to date in an extratropical marine environment. This paper described some of the key characteristics of the clouds, meteorology, aerosols, and precipitation at the Azores, including the seasonal cycle; diverse range of airmass histories; strong synoptic meteorological variability compared with other low-cloud regimes; and important bidirectional interactions 
(a)

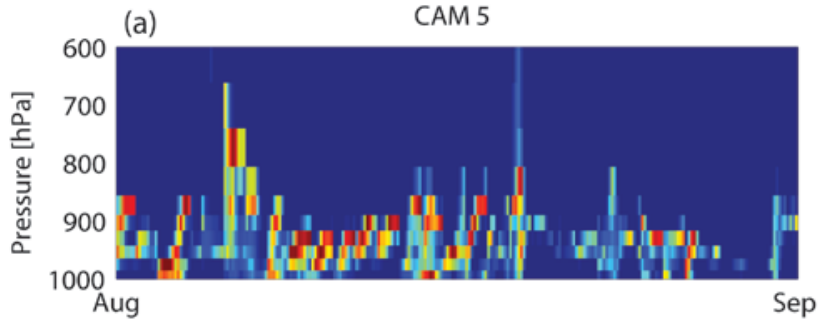

(b)

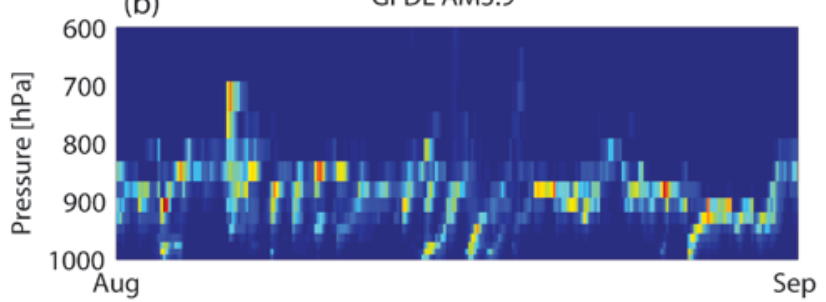

(c)

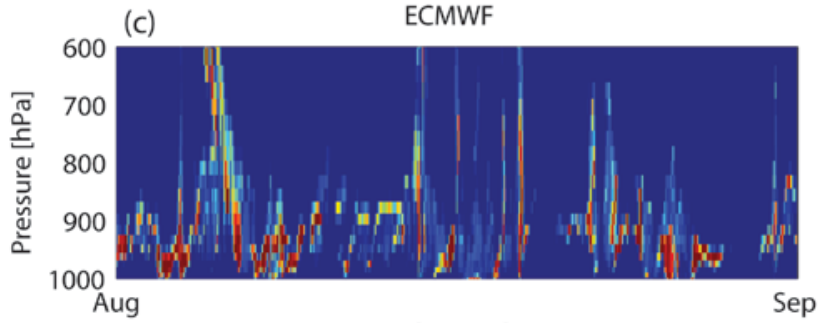

(d)

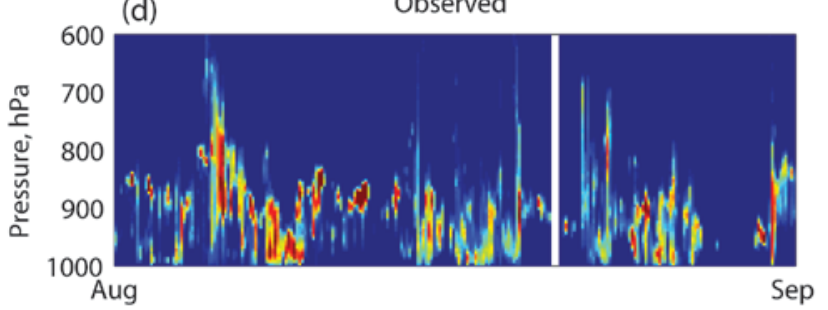

(e)

CAM 5

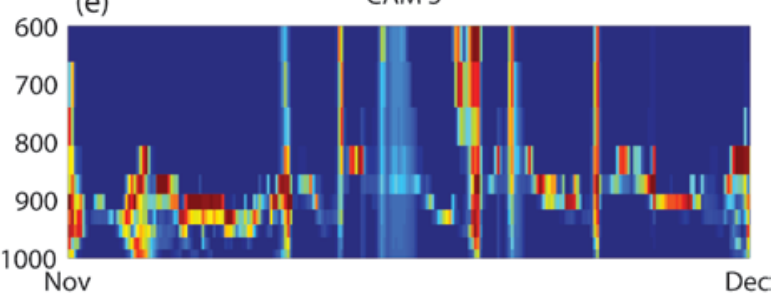

(f)

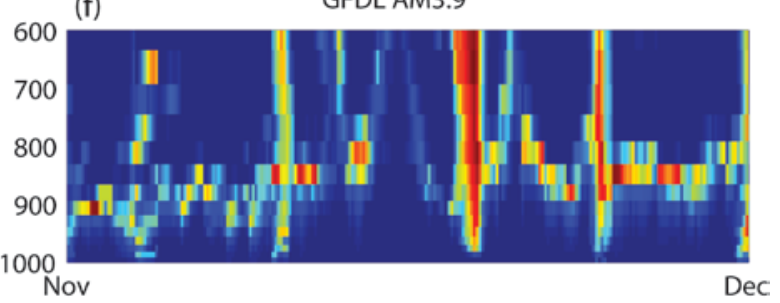

(g)

ECMWF

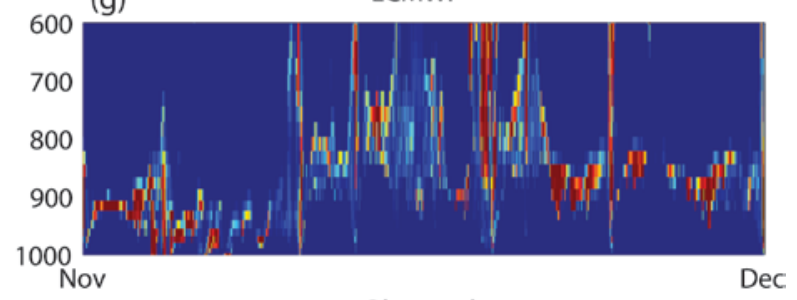

(h)

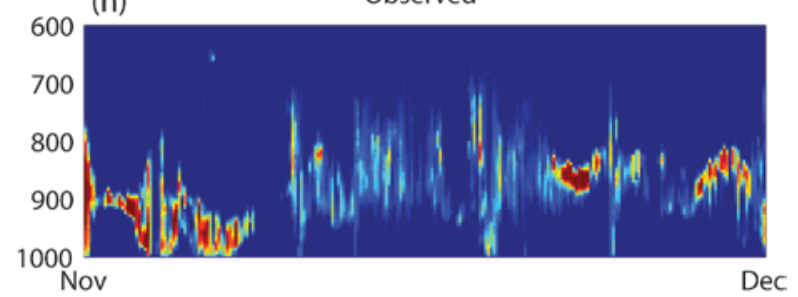

$\begin{array}{llllll}0 & 0.2 & 0.4 & 0.6 & 0.8 & 1\end{array}$

FIG. 14. Time-height plots of daily-mean lower-tropospheric cloud fraction simulated by models and AMF observations (based on the CloudNet cloud mask; Illingworth et al. 2007) for the dry and wet months.

between aerosols, clouds, and precipitation.

Although low clouds are the most frequently occurring cloud type, Graciosa is witness to a range of cloud types that are almost as diverse as those over Earth as a whole, making the site an excellent choice for continued measurements by ARM. However, these groundbased measurements and retrievals must be validated by aircraft in situ measurements in order to provide a ground truth for validating the satellite observations and retrievals and to provide model evaluation data. the observations.
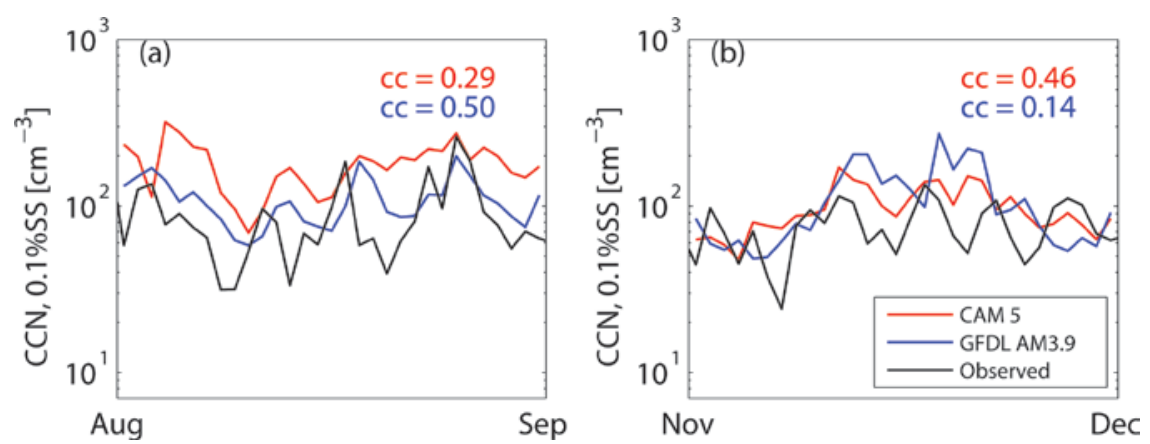

FIG. I5. Daily-mean CCN concentration at $0.1 \%$ supersaturation for the models and as measured at the Graciosa site. The colored numbers for each month are temporal correlation coefficients between $\log (\mathrm{CCN})$ for each model vs

In addition, the island site does not allow representative measurements of the surface heat and moisture fluxes over the ocean, but buoy measurements near 
Graciosa could potentially provide these. Given the great variety of aerosol, cloud, and precipitation conditions, the data from CAP-MBL and from the permanent site (in operation as of late 2013 and most of the instruments were fully functional in late 2014) will continue to challenge understanding and provide an unprecedented dataset for the evaluation and improvement of numerical models from cloudresolving ones to global weather and climate models.

ACKNOWLEDGMENTS. The CAP-MBL deployment of the ARM Mobile Facility was supported by the U.S. Department of Energy (DOE) Atmospheric Radiation Measurement Program (ARM) Climate Research Facility and the DOE Atmospheric Sciences Program. We are indebted to the scientists and staff who made this work possible by taking and quality controlling the measurements. Data were obtained from the ARM archive, sponsored by DOE, Office of Science, Office of Biological and Environmental Research Environmental Science Division. This work was supported by DOE Grants DESC0006865MOD0002 (PI Robert Wood), DE-SC0008468 (PI Xiquan Dong), DE-SC0006736 (PI David Mechem), DE-SC0000991 (PI Patrick Minnis), DESC0006712 (PI George Tselioudis), DE- SC0007233 (PI Christine Chiu), and DE-SC0006701 (PI Sandra Yuter). The CloudSat data were distributed by the CloudSat Data Processing Center at Colorado State University. MODIS data were obtained from the NASA Goddard Land Processes data archive. VOCALS data were obtained from the Earth Observation Laboratory (EOL) at the National Center for Atmospheric Research. The HYSPLIT IV model was obtained from the NOAA/Air Resources Laboratory. Data from the Aerosol Robotic Network (AERONET) were obtained from the web download tool hosted by NASA Goddard Space Flight Center.

\section{REFERENCES}

Ackerman, A. S., M. P. Kirkpatrick, D. E. Stevens, and O. B. Toon, 2004: The impact of humidity above stratiform clouds on indirect aerosol climate forcing. Nature, 432, 1014-1017, doi:10.1038/nature03174.

Ahlgrimm, M., and R. Forbes, 2014: Improving the representation of low clouds and drizzle in the ECMWF model based on ARM observations from the Azores. Mon. Wea. Rev., 142, 668-685, doi:10.1175/MWR -D-13-00153.1.

Albrecht, B. A., 1989: Aerosols, cloud microphysics, and fractional cloudiness. Science, 245, 1227-1230, doi:10.1126/science.245.4923.1227.

Andrews, E., and Coauthors, 2011: Climatology of aerosol radiative properties in the free troposphere.
Atmos. Res., 102, 365-393, doi:10.1016/j.atmosres .2011.08.017.

Bodhaine, B. A., 1996: Aerosol measurements during the Mauna Loa Photochemistry Experiment 2. J. Geophys. Res., 101, 14757-14765, doi:10.1029/95JD02045.

Bretherton, C. S., M. Widmann, V. P. Dymnikov, J. M. Wallace, and I. Blade, 1999: Effective number of degrees of freedom of a spatial field. J. Climate, 12, 1990-2009, doi:10.1175/1520 -0442(1999)0122.0.CO;2.

Burleyson, C. D., S. P. deSzoeke, S. E. Yuter, M. Wilbanks, and W. A. Brewer, 2013: Observations of the diurnal cycle of southeast Pacific marine stratocumulus clouds and precipitation. J. Atmos. Sci., 70, 38763894, doi:10.1175/JAS-D-13-01.1.

Chiu, J. C., A. Marshak, W. J. Wiscombe, S. C. Valencia, and E. J. Welton, 2007: Cloud optical depth retrievals from solar background "signal" of micropulse lidars. IEEE Geosci. Remote Sens. Lett., 4, 456-460, doi:10.1109/LGRS.2007.896722.

Clarke, A. D., and Coauthors, 1998: Particle nucleation in the tropical boundary layer and its coupling to marine sulfur sources. Science, 282, 89-92, doi:10.1126/science.282.5386.89.

- , and Coauthors, 2013: Free troposphere as the dominant source of CCN in the equatorial Pacific boundary layer: Long-range transport and teleconnections. Atmos. Chem. Phys., 13, 7511-7529, doi:10.5194/acp-13-7511-2013:

Comstock, K. K., R. Wood, S. E. Yuter, and C. S. Bretherton, 2004: Reflectivity and rain rate in and below drizzling stratocumulus. Quart. J. Roy. Meteor. Soc., 130, 2891-2918, doi:10.1256/qj.03.187.

Dee, D. P., and Coauthors, 2011: The ERA-Interim reanalysis: configuration and performance of the data assimilation system. Quart. J. Roy. Meteor. Soc., 137, 553-597, doi:10.1002/qj.828.

de Szoeke, S. P., S. Yuter, D. Mechem, C. Fairall, C. Burleyson, and P. Zuidema, 2012: Observations of stratocumulus clouds and their effect on the eastern Pacific surface heat budget along $20^{\circ} \mathrm{S}$. J. Climate, 25, 8542-8567, doi:10.1175/JCLI-D-11-00618.1.

Dong, X., T. P. Ackerman, and E. E. Clothiaux, 1998: Parameterizations of microphysical and shortwave radiative properties of boundary layer stratus from ground-based measurements. J. Geophys. Res., 103, 31 681-31 393, doi:10.1029/1998JD200047.

_ - B. Xi, A. Kennedy, P. Minnis, and R. Wood, 2014a: A climatology of marine aerosol-cloud-radiation derived from the DOE ARM Mobile Facility deployment at the Azores. Part I: Cloud fraction and single-layered MBL cloud properties. J. Climate, 27, 3665-3682, doi:10.1175/JCLI-D-13-00553.1. 
,-- , and P. Wu, 2014b: Investigation of the diurnal variation of marine boundary layer cloud microphysical properties at the Azores. J. Climate, 27, 8827-8835, doi:10.1175/JCLI-D-14-00434.1.

Draxler, R.R., 1999: HYSPLIT4 user's guide. NOAA Tech. Memo. ERL ARL-230, 35 pp. [Available online at www.arl.noaa.gov/documents/reports/arl-230 .pdf.]

Duong, H. T., A. Sorooshian, and G. Feingold, 2011: Investigating potential biases in observed and modeled metrics of aerosol-cloud-precipitation interactions. Atmos. Chem. Phys., 11, 4027-4037, doi:10.5194/acp-11-4027-2011.

Frisch, A. S., C. W. Fairall, and J. B. Snider, 1995: Measurement of stratus cloud and drizzle parameters in ASTEX with a Ka-band Doppler radar and a microwave radiometer. J. Atmos. Sci., 52, 2788-2799, doi:10.1175/1520-0469(1995)0522.0.CO;2.

Geoffroy, O., J.-L. Brenguier, and I. Sandu, 2008: Relationship between drizzle rate, liquid water path and droplet concentration at the scale of a stratocumulus cloud system. Atmos. Chem. Phys., 8, 4641-4654, doi:10.5194/acp-8-4641-2008.

Ghan, S. J., and Coauthors, 2013: A simple model of global aerosol indirect effects. J. Geophys. Res. Atmos., 118, 6688-6707, doi:10.1002/jgrd.50567.

Honrath, R. E., and Coauthors, 2004: Regional and hemispheric impacts of anthropogenic and biomass burning emissions on summertime $\mathrm{CO}$ and $\mathrm{O}_{3}$ in the North Atlantic lower free troposphere. J. Geophys. Res., 109, D24310, doi:10.1029/2004JD005147.

Hoose, C., J. E. Kristjánsson, T. Iversen, A. Kirkevåg, Ø. Seland, and A. Gettelman, 2009: Constraining cloud droplet number concentration in GCMs suppresses the aerosol indirect effect. Geophys. Res. Lett., 36, L12807, doi:10.1029/2009GL038568.

Illingworth, A. J., and Coauthors, 2007: Cloudnet. Bull. Amer. Meteor. Soc., 88, 883-898, doi:10.1175 /BAMS-88-6-883.

Isaksen, I. S. A., and Coauthors, 2009: Atmospheric composition change: Chemistry-climate interactions. Atmos. Environ., 43, 5138-5192, doi:10.1016/j .atmosenv.2009.08.003.

Jefferson, A., 2010: Empirical estimates of CCN from aerosol optical properties at four remote sites. Atmos. Chem. Phys., 10, 6855-6861, doi:10.5194/acp-10 -6855-2010.

Kafle, D. N., and R. L. Coulter, 2013: Micropulse lidar-derived aerosol optical depth climatology at ARM sites worldwide. J. Geophys. Res. Atmos., 118, 7293-7308, doi:10.1002/jgrd.50536.

Kooperman, G. J., M. S. Pritchard, S. J. Ghan, M. Wang, R. C. J. Somerville, and L. M. Russell, 2012:
Constraining the influence of natural variability to improve estimates of global aerosol indirect effects in a nudged version of the Community Atmosphere Model 5. J. Geophys. Res., 117, D23204, doi:10.1029/2012JD018588.

Kubar, T., D. L. Hartmann, and R. Wood, 2009: Understanding the importance of microphysics and macrophysics for warm rain in marine low clouds. Part I: Satellite observations. J. Atmos. Sci., 66, 2953-2972, doi:10.1175/2009JAS3071.1.

Leahy, L. V., R. Wood, R. J. Charlson, C. A. Hostetler, R. R. Rogers, M. A. Vaughan, and D. M. Winker, 2012: On the nature and extent of optically thin marine low clouds. J. Geophys. Res., 117, D22201, doi:10.1029/2012JD017929.

L'Ecuyer, T. S., W. Berg, J. Haynes, M. Lebsock, and T. Takemura, 2009: Global observations of aerosol impacts on precipitation occurrence in warm maritime clouds. J. Geophys. Res., 114, D09211, doi:10.1029/2008JD011273.

Liang, Q., L. Jaeglé, D. A. Jaffe, P. Weiss-Penzias, A. Heckman, and J. A. Snow, 2004: Long-range transport of Asian pollution to the northeast Pacific: Seasonal variations and transport pathways of carbon monoxide. J. Geophys. Res., 109, D23S07, doi:10.1029/2003JD004402.

Liu, J., and Z. Li, 2014: Estimation of cloud condensation nuclei concentration from aerosol optical quantities: Influential factors and uncertainties. Atmos. Chem. Phys., 14, 471-483, doi:10.5194/acp-14-471-2014.

Logan, T., B. Xi, and X. Dong, 2014: Aerosol properties and their influences on marine boundary layer cloud condensation nuclei at the ARM mobile facility over the Azores. J. Geophys. Res., 119, doi:10.1002/2013JD021288.

Lohmann, U., and J. Feichter, 2005: Global indirect aerosol effects: A review. Atmos. Chem. Phys., 5, 715, doi:10.5194/acp-5-715-2005.

Luke, E. P., and P. Kollias, 2013: Separating cloud and drizzle radar moments during precipitation onset using Doppler spectra. J. Atmos. Oceanic Technol., 30, 1656-1671, doi:10.1175/JTECH-D-11-00195.1.

Mann, J. A. L., J. C. Chiu, R. J. Hogan, E. J. O'Connor, T. S. L'Ecuyer, T. H. M. Stein, and A. Jefferson, 2014: Aerosol impacts on drizzle properties in warm clouds from ARM Mobile Facility maritime and continental deployments. J. Geophys. Res. Atmos., 119, 4136-4148, doi:10.1002/2013JD021339.

Mauritsen, T., and Coauthors, 2011: An Arctic CCNlimited cloud-aerosol regime. Atmos. Chem. Phys., 11, 165-173, doi:10.5194/acp-11-165-2011.

Mechoso, C. R., and Coauthors, 2014: Ocean-cloudatmosphere-land interactions in the southeastern 
Pacific: The VOCALS program. Bull. Amer. Meteor. Soc., 95, 357-375, doi:10.1175/BAMS-D-11-00246.1.

Minnis, P., and Coauthors, 2008: Near-real time cloud retrievals from operational and research meteorological satellites. Remote Sensing of Clouds and the Atmosphere XIII, R. H. Picard et al., Eds., International Society for Optical Engineering (SPIE Proceedings, Vol. 7107), 1-8, doi:10.1117/12.800344.

— , and Coauthors, 2011: CERES edition-2 cloud property retrievals using TRMM VIRS and Terra and Aqua MODIS data-Part I: Algorithms. IEEE Trans. Geosci. Remote Sens., 49, 4374-4400, doi:10.1109 /TGRS.2011.2144601.

Muhlbauer, A., I. McCoy, and R. Wood, 2014: Climatology of stratocumulus cloud morphologies: Microphysical and radiative properties. Atmos. Chem. Phys., 14, 6695-6716, doi:10.5194/acp-14-6695-2014.

O’Connor, E. J., R. J. Hogan, and A. J. Illingworth, 2005: Retrieving stratocumulus drizzle parameters using Doppler radar and lidar. J. Appl. Meteor., 44, 14-27, doi:10.1175/JAM-2181.1.

Penner, J. E., and Coauthors, 2006: Model intercomparison of indirect aerosol effects. Atmos. Chem. Phys., 6, 3391-3405, doi:10.5194/acp-6-3391-2006.

Petters, M. D., J. R. Snider, B. Stevens, G. Vali, I. Faloona, and L. Russell, 2006: Accumulation mode aerosol, pockets of open cells, and particle nucleation in the remote subtropical Pacific marine boundary layer. J. Geophys. Res., 111, D02206, doi:10.1029/2004JD005694.

Phillips, T. J., and Coauthors, 2004: Evaluating parameterizations in general circulation models: Climate simulation meets weather prediction. Bull. Amer. Meteor. Soc., 85, 1903-1915, doi:10.1175/BAMS-85-12-1903.

Platnick, S., and S. Twomey, 1994: Determining the susceptibility of cloud albedo to changes in droplet concentration with the Advanced Very High Resolution Radiometer. J. Appl. Meteor., 33, 334-347, doi:10.1175/1520-0450(1994)0332.0.CO;2.

—, M. D. King, S. A. Ackerman, W. P. Menzel, B. A. Baum, J. C. Riedi, and R. A. Frey, 2003: The MODIS cloud products: Algorithms and examples from Terra. IEEE Trans. Geosci. Remote Sens., 41, 459-473, doi:10.1109/TGRS.2002.808301.

Quaas, J., and Coauthors, 2009: Aerosol indirect effects-General circulation model intercomparison and evaluation with satellite data. Atmos. Chem. Phys., 9, 8697-8717, doi:10.5194/acp-9-8697-2009.

Rauber, R. M., and Coauthors, 2007: Rain in shallow cumulus over the ocean. Bull. Amer. Meteor. Soc., 88, 1912-1928, doi:10.1175/BAMS-88-12-1912.

Rémillard, J., P. Kollias, E. Luke, and R. Wood, 2012: Marine boundary layer cloud observations at the
Azores. J. Climate, 25, 7381-7398, doi:10.1175/JCLI -D-11-00610.1.

Sharon, T. M., B. A. Albrecht, H. Jonsson, P. Minnis, M. M. Khaiyer, T. M. VanReken, J. Seinfeld, and R. Flagan, 2006: Aerosol and cloud microphysical characteristics of rifts and gradients in maritime stratocumulus clouds. J. Atmos. Sci., 63, 983-997, doi:10.1175/JAS3667.1.

Sorooshian, A., G. Feingold, M. D. Lebsock, H. Jiang, and G. L. Stephens, 2010: Deconstructing the precipitation susceptibility construct: Improving methodology for aerosol-cloud precipitation studies. J. Geophys. Res., 115, D17201, doi:10.1029/2009JD013426.

Stevens, B., and G. Feingold, 2009: Untangling aerosol effects on clouds and precipitation in a buffered system. Nature, 461, 607-613, doi:10.1038/nature08281. _, G. Vali, K. Comstock, R. Wood, M. Van Zanten, P. H. Austin, C. S. Bretherton, and D. H. Lenschow, 2005: Pockets of open cells and drizzle in marine stratocumulus. Bull. Amer. Meteor. Soc., 86, 51-57, doi:10.1175/BAMS-86-1-51.

Terai, C. R., R. Wood, D. C. Leon, and P. Zuidema, 2012: Does precipitation susceptibility vary with increasing cloud thickness in marine stratocumulus? Atmos. Chem. Phys., 12, 4567-4583, doi:10.5194/acp-12 $-4567-2012$.

, C. S. Bretherton, R. Wood, and G. Painter, 2014: Aircraft observations of five pockets of open cells sampled during VOCALS-REx. Atmos. Chem. Phys., 14, 8071-8088, doi:10.5194/acp-14-8071-2014.

Toledano, C., V. E. Cachorro, A. M. de Frutos, B. Torres, A. Berjon, M. Sorribas, and R. S. Stone, 2009: Airmass classification and analysis of aerosol types at El Arenosillo (Spain). J. Appl. Meteor. Climatol., 48, 962-981, doi:10.1175/2008JAMC2006.1.

Tselioudis, G., W. Rossow, Y. Zhang, and D. Konsta, 2013: Global weather states and their properties from passive and active satellite cloud retrievals. J. Climate, 26, 7734-7746, doi:10.1175/JCLI-D-13-00024.1.

Turner, D. D., 2007: Improved ground-based liquid water path retrievals using a combined infrared and microwave approach. J. Geophys. Res., 112, D15204, doi:10.1029/2007JD008530.

— - and Coauthors, 2007: Thin liquid water clouds: Their importance and our challenge. Bull. Amer. Meteor. Soc., 88, 177-190, doi:10.1175/BAMS-88-2-177. Val Martin, M., R. E. Honrath, R. C. Owen, and Q. B. Li, 2008: Seasonal variation of nitrogen oxides in the central North Atlantic lower free troposphere. J. Geophys. Res., 113, D17307, doi:10.1029/2007JD009688.

Warren, S. G., C. J. Hahn, J. London, R. M. Chervin, and R. L. Jenne, 1988: Global distribution of total cloud 
cover and cloud types over ocean. NCAR Tech. Note NCAR/TN-317+STR, 42 pp. + 170 maps.

Wood, R., 2005: Drizzle in stratocumulus. Part I: Horizontal and vertical structure. J. Atmos. Sci., 62, 3011-3034, doi:10.1175/JAS3529.1.

_ 2006: The rate of loss of cloud condensation nuclei by coalescence in warm clouds. J. Geophys. Res., 111, D21205, doi:10.1029/2006JD007553.

—, 2007: Cancellation of aerosol indirect effects in marine stratocumulus through cloud thinning. J. Atmos. Sci., 64, 2657-2669, doi:10.1175/JAS3942.1. _-, 2012: Stratocumulus clouds. Mon. Wea. Rev., 140, 2373-2423, doi:10.1175/MWR-D-11-00121.1.

— , and C. S. Bretherton, 2006: On the relationship between stratiform low cloud cover and lower tropospheric stability. J. Climate, 19, 6425-6432, doi:10.1175/JCLI3988.1.

—, K. K. Comstock, C. S. Bretherton, C. Cornish, J. Tomlinson, D. R. Collins, and C. Fairall, 2008: Open cellular structure in marine stratocumulus sheets. J. Geophys. Res., 113, D12207, doi:10.1029/2007JD009371.
-, T. Kubar, and D. L. Hartmann, 2009: Understanding the importance of microphysics and macrophysics for warm rain in marine low clouds. Part II: Heuristic models of rain formation. J. Atmos. Sci., 66, 2973-2990, doi:10.1175/2009JAS3072.1.

—, D. Leon, M. Lebsock, J. Snider, and A. D. Clarke, 2012: Precipitation driving of droplet concentration variability in marine low clouds. J. Geophys. Res., 117, D19210, doi:10.1029/2012JD018305.

Wyant, M. C., and Coauthors, 2010: The PreVOCA experiment: Modeling the lower troposphere in the southeast Pacific. Atmos. Chem. Phys., 10, 4757-4774, doi:10.5194/acp-10-4757-2010.

Zhang, M. H., and Coauthors, 2005: Comparing clouds and their seasonal variations in 10 atmospheric general circulation models with satellite measurements. J. Geophys. Res., 110, D15S02, doi:10.1029/2004JD005021.

Zhao, T. L., S. L. Gong, P. Huang, and D. Lavoué, 2012: Hemispheric transport and influence of meteorology on global aerosol climatology. Atmos. Chem. Phys., 12, 7609-7624, doi:10.5194/acp-12-7609-2012.

\section{NEW FROM AMS BOOKS!}

\section{The Thinking Person's Guide to Climate Change}

\section{Robert Henson}

Expanded and updated from Henson's Rough Guide to Climate Change, 3rd edition (no longer in print), combining years of data with recent research, including conclusions from the Fifth Assessment Report of the Intergovernmental Panel on Climate Change, the Guide breaks down the issues into straightforward categories:

$>$ Symptoms, including melting ice and extreme weather

$>$ Science, laying out what we know and how we know it

$>$ Debates, tackling the controversy and politics

$>$ Solutions and Actions for creating the best possible future

() 2014, 516 pages, paperback ISBN: 978-1-878220-73-7

List price: $\$ 30$ AMS Member price: $\$ 20$

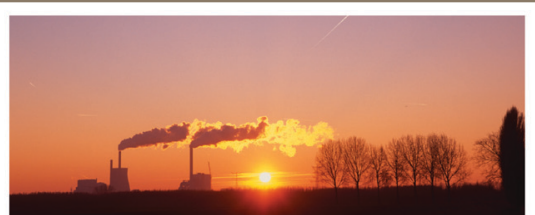

THE THINKING PERSON'S GUIDE TO CLIMATE CHANGE
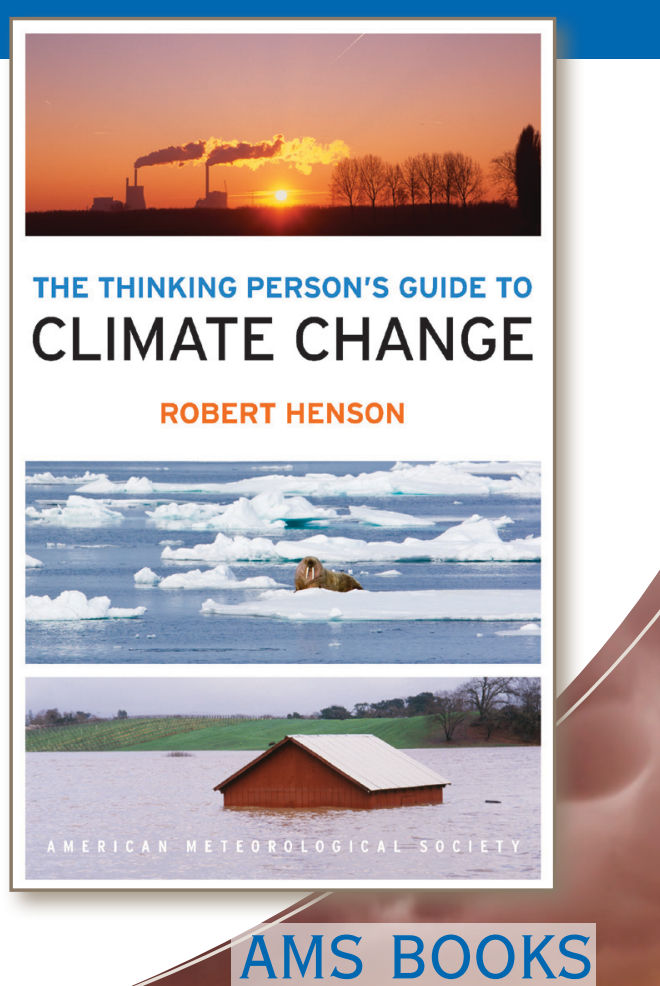

$>$ bookstore.ametsoc.org 


\section{$\infty$ the AMS online bookstore}

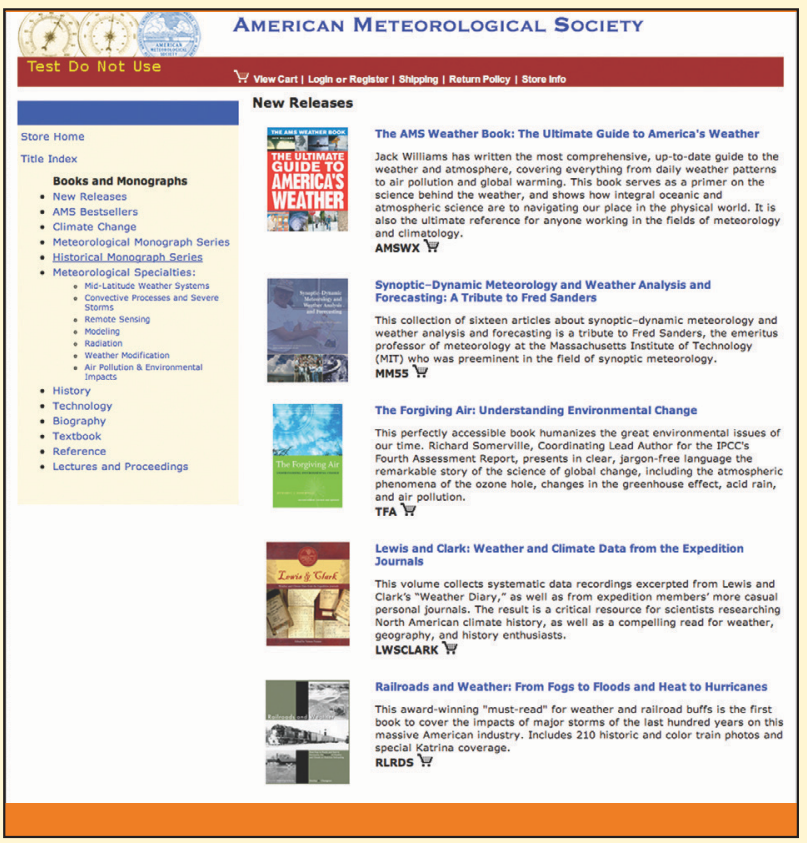

Use this easy-to-navigate site to review and purchase new and classic titles in the collection of AMS Books-including general interest weather books, histories, biographies, and monographsplus much more.

View tables of contents, information about the authors, and independent reviews.

As always, AMS members receive deep discounts on all AMS Books.

\section{www.ametsoc.org/amsbookstore The AMS online bookstore is now open.}

Booksellers and wholesale distributors may set up accounts with our distributor, The University of Chicago Press, by contacting Karen Hyzy at khyzy@press.uchicago.edu, 773-702-7000, or toll-free at 800-621-2736. 